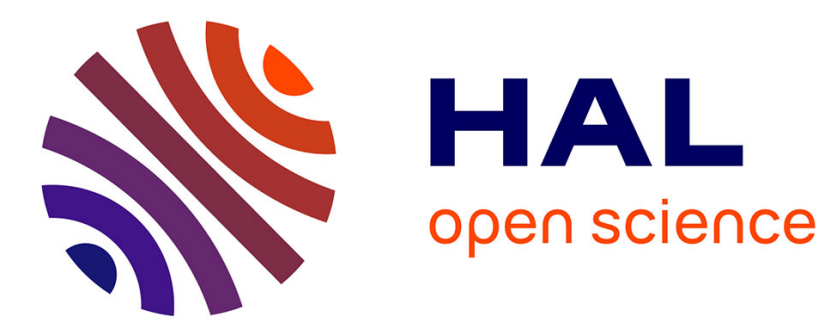

\title{
Shear band formation and strain localization on a regional scale: Evidence from anisotropic rocks below a major detachment (Betic Cordilleras, Spain)
}

Philippe Agard, Romain Augier, Patrick Monié

\section{- To cite this version:}

Philippe Agard, Romain Augier, Patrick Monié. Shear band formation and strain localization on a regional scale: Evidence from anisotropic rocks below a major detachment (Betic Cordilleras, Spain). Journal of Structural Geology, 2011, 33, pp.114-131. 10.1016/j.jsg.2010.11.011 . insu-00545043

\section{HAL Id: insu-00545043 \\ https://hal-insu.archives-ouvertes.fr/insu-00545043}

Submitted on 14 Dec 2010

HAL is a multi-disciplinary open access archive for the deposit and dissemination of scientific research documents, whether they are published or not. The documents may come from teaching and research institutions in France or abroad, or from public or private research centers.
L'archive ouverte pluridisciplinaire HAL, est destinée au dépôt et à la diffusion de documents scientifiques de niveau recherche, publiés ou non, émanant des établissements d'enseignement et de recherche français ou étrangers, des laboratoires publics ou privés. 


\title{
Shear band formation and strain localization on a regional scale: evidence from anisotropic rocks below a major detachment (Betic Cordilleras, Spain)
}

\author{
Agard P. ${ }^{1,}$, Augier R. ${ }^{2}$, Monié P. ${ }^{3}$ \\ ${ }^{1}$ UPMC Univ Paris 06, ISTEP, F-75005, Paris, France \\ ${ }^{1}$ CNRS, UMR 7193, ISTEP, F-75005, Paris, France \\ ${ }^{2}$ Univ Orléans, UMR 6113, ISTO, F-45071, Orléans, France \\ ${ }^{3}$ CNRS, Géosciences Montpellier, UMR 5243, F-34095, Montpellier, France
}

\begin{abstract}
Regional-scale deformation taking place in a strongly anisotropic, yet homogeneous metapelitic protolith during an apparently single tectonic event was systematically investigated as a function of the distance to the main tectonic contact (i.e., the Filabres shear zone, a major detachment in the Betic Cordilleras, Spain).

C3' shear bands (or extensional crenulation cleavage) reworking the earlier S2 schistosity increase steadily towards the contact, in parallel with the decrease in the size of the shear domains. Systematic variations in angles and shape ratios are also reported. Shear band density decreases exponentially as a function of the distance to the detachment. Deformation and age patterns, however, suggest that this spectacular trend does not correspond to a perfectly fossilized shear strain gradient but at least partly results from a progressive localization of the deformation through time. Such shear strain patterns nevertheless provide a mean to constrain the rheological properties for such weak lithologies and a mean to better understand crustal deformation.
\end{abstract}

keywords: shear bands; strain gradient; progressive deformation; cleavage; Betics

*corresponding author: philippe.agard@upmc.fr

fax: 0033 - 144275085 


\section{Introduction}

Ductile shear zones and shear band geometries have been studied extensively over the past 40 years (e.g., Ramsay and Graham, 1970; Burg and Laurent, 1978; Berthé et al., 1979; Ramsay, 1980; Gapais et al., 1987; Dutruge et al., 1995; Carreras, 2001; Battacharya and Hudleston, 2001; Arbaret and Burg, 2003; Michibayashi and Murakami, 2007). These studies focused on geometrical patterns (Passchier, 1998), on determining the respective contributions of simple and pure shear (Ramsay and Huber, 1983; Tikoff and Fossen, 1993), or on retrieving the history of deformation (Druguet et al., 1997; Carreras et al., 2010). So far most of them dealt with individual structures at the outcrop scale (eg., Arbaret and Burg, 2003; Pennachioni and Mancktelow, 2007) or on their organization as networks (particularly on the Cap de Creus area; e.g., Druguet et al., 1997; Carreras, 2001; Fusseis et al., 2006).

Fewer, however, attempted to trace finite deformation on a regional scale, for example as a function of the distance to a major crustal shear zone (Stipp et al., 2002; Gueydan et al., 2005; Marques et al., 2007), although such patterns bear important information on the rheological evolution of strain localization. This is particularly important for the weaker, phyllosilicate-rich, schistosed lithologies, which will tend to predominantly focus deformation and thus control mid-crustal deformation (e.g., Shea and Kronenberg, 1993; Handy and Brun, 2004; Le Pourhiet et al., 2004 and references therein). Initially homogeneous, isotropic rock volumes with round or spherical initial markers, such as deformed granites or gabbros transformed to mylonites or ultramylonites (Choukroune and Gapais, 1983; Arbaret and Burg, 2003), commonly develop C-S and C'-S structures (Berthé et al., 1979; Ramsay, 1980; Hippert, 1999) and exhibit some periodicity in the localization of shear strain (Cobbold and Ferguson, 1979; Dutruge et al., 1995; Dutruge and Burg, 1997; Gueydan et al., 2003). In 
contrast, phyllosilicate-rich lithologies deformed through bulk simple shear, or with the principal strain oriented at high angle to the plane of anisotropy, will tend to develop spaced shear bands termed extensional crenulation cleavage (ECC, Platt, 1979; or shear band cleavage: White et al., 1980).

How these multi-scale shear fabrics progressively develop in anisotropic rocks with increasing shear strain is still unclear, with constrating evidence of strain localization or network widening (Passchier, 1984; Platt, 1984; Fusseis et al., 2006; Handy et al., 2007; Michibayashi and Murakami, 2007; Scholz, 2007), and even caution as to whether they reflect the overall sense of shear (Behrmann, 1987; Passchier, 2001; Grasemann et al., 2003; Lexa et al., 2004). Important pending questions are: is it therefore possible to derive an empirical law relating the regional-scale shear strain gradient to deformation patterns in metapelitic shear zones (which could, in turn, be used as a way to constrain their hardening/softening behaviour or strain rates; e.g., Means, 1995; Sassier et al., 2009)? How much deformation is taken up near a major contact at the $\mathrm{hm}$ - to $\mathrm{km}$-scale, and how much tectonic thinning is involved? Can we quantify the amount of ductile deformation and provide constraints for numerical models attempting to reproduce rheological behaviours as seen in rocks (e.g., Jessell et al., 2009)?

The area investigated here, where ECCs were first defined (Betic Cordilleras, Spain; Platt, 1979; Platt \& Vissers, 1980), exhibits a stack of rocks exhumed below a major detachment. This regional-scale detachment, with a strike $>150 \mathrm{~km}$, separates the Alpujarride from the Nevado-Filabride complexes and is well known in terms of deformation and P-Ttime history (Platt \& Vissers, 1980; Platt et al., 1984; Garcia-Dueñas et al., 1992; MartínezMartínez et al., 2002; Augier et al., 2005a). Importantly, the shear band network investigated here can be thought to result from a single deformation event exhuming these rocks at 350 $480^{\circ} \mathrm{C}$ (D3 stage; Augier et al., 2005b), hence essentially from below the frictional-to-viscous transition (Handy et al., 2007). Rocks found below the contact are strongly anisotropic 
metapelites with shear cleavages superimposed on an earlier, pervasive, flat-lying schistosity and are chemically and structurally homogeneous at the km-scale (i.e., Paleozoic dark schists with an ubiquitous, upper greenschist facies garnet-chloritoid-chlorite-phengite assemblage aligned along the S2 schistosity).

This area thus provides a unique opportunity to study the deformation of a strongly anisotropic yet homogeneous body with well-exposed XZ sections on a regional-scale, a clear deformation gradient (Platt et al., 1984) and asymmetric tectonic patterns (Augier et al., 2005a). We herein characterize the distribution of shear bands and shear geometries as a function of the distance to the Filabres shear zone through systematic, statistically significant measurements. The strategy adopted here is closely related to the one outlined by Choukroune et al. (1987), who stated that « useful approaches could perhaps involve statistical studies of geometric features (e.g. orientations, length, spacing and population density of structures) and of their correlations with the amount of bulk shear strain. »

\section{Geological setting and deformation style}

\subsection{The Nevado-Filabride complex within the Betic orogen}

The Betic-Rif orogen results from the closure of the westernmost part of the Tethys ocean between Africa and the Iberian Peninsula (Fig. 1a). Subduction and crustal thickening leading to the formation of HP-LT metamorphic units took place from the Eocene to the Oligocene and were followed by late-orogenic extension starting after c. 35-30 $\mathrm{Ma}$ in the western Mediterranean (Platt et al., 1998; Jolivet \& Faccenna, 2000). Lithospheric-scale causes of late 
orogenic extension are still debated, with contrasting models based on slab retreat (Royden, 1993; Lonnergan \& White, 1997; Jolivet et al., 2008), delamination of subcontinental lithosphere (Martínez-Martínez \& Azañón, 1997; Calvert et al., 2000) or convective removal of thickened crust (Platt \& Vissers, 1989; Vissers et al., 1995).

The internal zones of the Betic Cordilleras correspond to the initial stacking of the Nevado-Filabride, Alpujarride and Malaguide complexes (from bottom to top; Fig. 1b), currently separated from each other by major crustal-scale extensional shear zones: the Filabres Shear Zone (hereafter FSZ: García-Dueñas et al., 1992; BMZ in Platt and Vissers, 1989) and the Malaguide-Alpujarride Contact (MAC, Vissers et al., 1995), respectively. The age of the peak of pressure for the Nevado-Filabride (NF) complex is not precisely known but recent age constraints place it at around $30 \mathrm{Ma}$ and possibly older (Augier et al., 2005b). Exhumation of the NF complex took place through a roughly E-W regional penetrative ductile extension from 30 to 18-14 Ma (García-Dueñas et al., 1992; Martínez-Martínez et al., 2002; Augier et al., 2005b).

\subsection{Deformation history of the Nevado-Filabride complex}

The Nevado-Filabride complex is composed of three main tectonic units which are, from bottom to top (Fig. 1c; Martínez-Martínez et al., 2002 and references therein), the Ragua, Calar Alto and Bédar-Macael units, with respective structural thicknesses of 4000, 4500 and $600 \mathrm{~m}$ (García-Dueñas et al., 1988; the latter two being also refered to as the Mulhacen complex). These three units present a roughly similar lithostratigraphic succession (as for the Alpujarride units) with a thick and monotonous sequence of presumably Palaeozoic dark, graphitic micaschists and microturbidites topped by light coloured Permo-Triassic micaschists and quartzites and Triassic carbonate rocks (Lafuste \& Pavillon, 1976; Platt et al., 1984). 
These units are separated by major (i.e. $>500 \mathrm{~m}$ thick) ductile to ductile-brittle shear zones (Platt et al., 1984; García-Dueñas et al., 1988; González-Casado et al., 1995). The most complete section of the NF complex can be found in the Sierra de los Filabres where it is bounded by the FSZ (Fig. 1a,b; Platt et al., 1984).

The Nevado-Filabride complex primarily shows a succession of deformation phases during exhumation (here labelled D2 and D3) interpreted as a continuum of strain localization, with a progressive evolution from the ductile to the brittle D4 regime across the frictional-viscous transition (Augier et al., 2005a; Handy et al., 2007). While the burial D1 stage is only preserved in the core of the NF complex, D2 is characterised by the development in most of the NF complex of a generally gently dipping, planar-linear fabric $\left(\mathrm{S}_{2}-\mathrm{L}_{2}\right)$, axialplanar to $F_{2}$ folds (Fig. 2a). The $S_{2}$ foliation carries a strong and penetrative E-W stretching lineation $\left(\mathrm{L}_{2}\right)$ which is more intense toward the major extensional contacts, in particular the FSZ, and marked by the progressive disappearance of $S_{0}$ and $S_{1}$ features (Augier et al., 2005a; Fig. 2a). Kinematic indicators (absent or rare in the core of the complex) also increase near the FSZ and indicate an overall top-to-the-west sense of shear (e.g., González-Casado et al., 1995; Martínez-Martínez et al., 2002).

The combination of metamorphic petrology and in situ laser ${ }^{40} \mathrm{Ar} /{ }^{39} \mathrm{Ar}$ dating on phengite (linking time of growth, compositions and P-T conditions; Agard et al., 2002) enabled us to identify a detailed P-T-d-t path for the Nevado-Filabride complex (Fig. 2c; Augier et al., 2005b). Data show an isothermal decompression (at $550^{\circ} \mathrm{C}$ ) from $18-20$ kbar for the BédarMacael unit and 14 kbar for the Calar Alto unit down to approximately 3-5 kbar for both units at exhumation rates of $\sim 2.8 \mathrm{~mm} . \mathrm{yr}^{-1}$.

\subsection{Shear band (ECC) formation during the D3 stage}


All previous structures, particularly in the highest part of the NF complex, are affected by a late D3 shear cleavage (or ECC; Platt \& Vissers, 1980; Platt, 1984) noted $\mathrm{C}_{3}{ }^{\prime}$ hereafter. Finite strain and the degree of non-coaxiality increase near the Filabres shear zone (FSZ) detachment, where this D3 cleavage is highly pervasive and previous structures are overprinted (Fig. 2b). Synthetic, top-to-the west $\mathrm{C}_{3}{ }^{\prime}$ shear bands largely dominate in the field. The incentive for our study came from the observation that the spacing of these $\mathrm{C}_{3}{ }^{\prime}$ shear bands apparently evolved as a function of the distance to the detachment.

In much the same way as D2, the D3 deformation stage shows marked top-to-the-west shear sense indicators (Augier et al., 2005a). The relationship between these deformation patterns and the regional-scale tectonic setting detailed elsewhere (Augier et al.; 2005a,b; Jolivet et al., 2008). Following D2 (22-18 Ma), this D3 stage took place from 18 Ma to 14 $\mathrm{Ma}$ at pressures of 3-5 kbars for a temperature range of $350-480^{\circ} \mathrm{C}$ (see Fig. $2 \mathrm{~d}$ for details), and is thought to mark the transition from syn- to post-orogenic exhumation (Jolivet et al., 2008). This second part of the exhumation shows exhumation rates on the order of $0.6 \mathrm{~mm}$. $\mathrm{yr}^{-}$ ${ }^{1}$ along a HT-LP gradient of $\sim 60^{\circ} \mathrm{C} \cdot \mathrm{km}^{-1}$. The transition from ductile to brittle occurred later at around $14 \mathrm{Ma}$.

The final exhumation, from $\sim 14$ to $9 \mathrm{Ma}$, was constrained by fission-track ages on zircon and apatite (Johnson et al., 1997) and accommodated by brittle deformation along the FSZ (D4 stage, not studied here; Fig. 2a; Augier et al., 2005a). It was accompanied from 12 to 8 Ma by the formation of adjacent extensional basins, mostly infilled from the SerravallianTortonian boundary (c. 11.6 Ma) to the Plio-Quaternary, with evidence of syn-tectonic infill related to the exhumation of the NF complex. From the late Miocene (c. $8 \mathrm{Ma}$ ) onwards, the area has been under a roughly NS compression, which refolded the FSZ (and the Filabres ridge) into an open to locally overturned anticline (Martinez-Martinez et al., 2002). 
Overall vertical shortening estimates during D3, though probably not homogeneous throughout the rock pile, can be crudely bracketed: since maximum pressure differences between samples taken close to the contact and others taken c. $700 \mathrm{~m}$ away amount to $0,3-0,5$ kbar (c. 1-1,2 km difference; Augier et al., 2005b), the section investigated here has therefore been shortened by a factor of $\sim 1,5$ at the most. In the absence of constraints for horizontal displacement, deformation rates can not be estimated, unfortunately.

\section{Tracking deformation as a function of the distance to the Filabres shear zone}

The increase in the number of $\mathrm{C}_{3}$ ' shear bands towards the contact is the main focus of this paper and is most visible at the scale of the outcrop, i.e. at the meter scale. This is consistent with previous reports of a deformation gradient decreasing away from the contact in the NF complex down to $400 \mathrm{~m}$ (e.g., Platt et al., 1984).

To ensure that our report on meter-scale structures was representative of the overall strain partitioning and was not omitting deformation from possibly larger structures (see Lister and Williams, 1979), foliation strike and dip were systematically measured (for the sake of clarity, about half only of the values are plotted on Fig. 3a) and the whole of the area was carefully inspected. No larger-scale (i.e., km- or hm-scale) shear bands have been detected on the field, either by field inspection or from schistosity variations (see Fig. 3) . Only few late brittle faults, typically $50 \mathrm{~m}$ long, crosscut the area with an irregular spacing on the order of c. 100$150 \mathrm{~m}$.

\subsection{Outcrop selection}


Twenty-two outcrops were selected carefully at various distances to the shear zone (Fig. 3c; Table 1). The best exposures are found along the roughly E-W Filabres ridge (Fig. 3d), which exhibits an almost flat-lying, gently N- to NE-dipping schistosity with well aligned EWtrending lineations throughout, and provides excellent XZ exposures. In order to outline the main correlation trends in the data, our sites are grouped according to five zones, I to V, for distances comprised between $>500 \mathrm{~m}, 500-250 \mathrm{~m}, 250-100 \mathrm{~m}, 100-30 \mathrm{~m}$ and $30-0 \mathrm{~m}$, respectively.

Distances to the contact between the NF and Alpujarride units were directly measured on foot for sites 4-7 (e.g., Fig. 4a). For other sites, the distance was calculated by interpolating the geometry of the detachment (isohypses from the detachment are shown on Fig 3c). This geostatistical approach (using ArcGIS software; e.g., Isaaks and Srivastava, 1989) allows to predict spatial patterns of variables and attribute values at non sampled locations, assuming here (1) the most simple interpolation for the detachment between the various Alpujarride klippens of the area (Fig. 1) and (2) that the detachment is involved in a gentle, roughly E-W anticline parallel to the Filabres ridge (whose axial trace fits the dome axis; see Figs. 1, 3). Distances and corresponding uncertainties are listed in Table 1.

The twenty-two sites were chosen because of their representative average density of shear bands (i.e., with respect to outcrops a few tens of meters apart). The choice of a representative area is critical and requires further justification. This was only done after a very careful inspection of several possible XZ exposures. Areas were finally chosen so that (1) their dimensions would be larger than the average length of the shear bands, (2) the shear band density looked "average" with respect to other outcrops and (3) as homogeneous as possible. Schrank et al. (2008) have proposed an elegant way, using auto-correlation techniques (their Fig. 2a and Appendix), to ensure the representativeness of the areas chosen. Their method is unfortunately not applicable to our outcrops, since the deflection of initial markers can not be 
assessed reliably from image analysis of field photographs. Our method was nevertheless validated by both the internal consistency of the results and the similar values of the shear band density obtained for neighbouring sites (see below). In any case, one should be aware that none of these methods unfortunately prevents from choosing "wrong" outcrops (i.e., irrelevant outcrops which would not be representative).

All chosen surfaces correspond to $\mathrm{XZ}$ planes with minimum vegetation: they are parallel to the $\mathrm{L}_{2-3}$ lineation and perpendicular to the $\mathrm{S}_{2}$ and $\mathrm{C}_{3}$ ' shear bands. Note, incidentally, that mostly synthetic $\mathrm{C}_{3}{ }^{\prime}$ shear bands are visible in the field. Most measurements were performed across E-W vertical cliffs, with the strikes of $\mathrm{S}_{2}$ and $\mathrm{C}_{3}{ }^{\prime}$ thus close to horizontal. The only exception is for sites $4 \mathrm{a}, \mathrm{b}$, where $\mathrm{S}_{2}$ and $\mathrm{C}_{3}$ ' were overturned by the late Miocene compression and are now close to vertical (Jolivet et al., 2006; Do Couto et al., 2010). We finally stress that the garnet-chloritoid-phengite-chlorite assemblage is well-preserved in all outcrops (Figs. $4 b, 6 c)$.

\subsection{Meter-scale deformation patterns}

We briefly describe in the following the evolution of the style of deformation at the meter scale at increasing distances from the contact (see Figs. 4,5):

- Zone V (e.g., sites 6, 7A: $<30 \mathrm{~m}$ away from the contact):

This domain is represented by extremely deformed phyllonites (mylonites to, locally, ultramylonites) with shear bands $<\mathrm{cm}$ on average. This intense deformation precludes measuring reliably shear band dimensions and angles, and only the characteristic shape ratios of the shear domains (see $\S 4.1$ ) were measured.

- Zone IV (e.g., sites 4A-B: $50 \mathrm{~m}$ away from the contact; Fig. 4a): 
$\mathrm{C}_{3}$ ' shear bands dominate and are completely transecting the S2, only preserved in the microlithons and appear as the main macroscopic fabric of the outcrops. These structures are strongly pervasive and homogeneous (Fig. 4b-e). Shear bands longer than 0,5-1 m were not found (Fig. 4b), nor any evidence for a relative chronology amongst them. D3 deformation is also intense at the cm-mm scale (Fig. 4f), yet exclusively in sites located $<\sim 100 \mathrm{~m}$ below the Filabres shear zone. Structures are very similar for site 4C (70 m away from the contact; zone IV; Fig. 4g,h), with less impressive $\mathrm{C}_{3}$ ' bands however, which is probably due to site $4 \mathrm{C}$ surfaces being vertical and less weathered than those of sites $4 \mathrm{~A}, \mathrm{~B}$.

- Zone III (e.g., sites 3A-B: 145 and 180 m away from the contact, respectively, Figs. $5 \mathrm{a}, \mathrm{b})$ :

These outcrops show larger-scale shear bands partly anastomosing (Fig. 5a). Unlike zone IV, cm-scale and smaller shear bands are not observed. The minimum spacing between the shear bands is on the order of 4-5 cm. Early $\mathrm{cm}$-scale veins formed during D1 are flattened and folded. The shear band spacing may in part be controlled by the late Qtz-Cc+-Chl veins (right side of Fig. 5a), which formed between D2 and D3. In site 3B, which is slightly farther away from the contact but also more quartz-rich than 3A (compare Fig. 5a,b), fewer shear bands are found.

- Zone II (e.g., sites 2A-C, $>250 \mathrm{~m}$ away from the contact; Figs. 5c-e):

The five sites of this zone were chosen at distances 10-100 m apart on the field. Once again shear bands are rather evenly distributed, with a characteristic spacing of $\sim 30-50 \mathrm{~cm}$. More greenschist veins are found in site $2 \mathrm{~A}$. Site $2 \mathrm{C}$ is cut across by a somewhat larger shear band than the other two sites on which shear band cleavages were measured.

- Zone I (e.g., site 1: 700 m away from the contact; Fig. 5f):

At such distances, D3 deformation is almost unnoticed, with a dominant, conspicuous D2 foliation. There are so few $\mathrm{C}_{3}$ ' shear bands that the choice of a representative area is difficult. 
Spacing of the shear bands is typically on the m-scale and the representative area extends over more than $10 \mathrm{~m}^{2}$. The angle between shear band cleavage and S2, $\alpha$ (Fig. 6a), was clearly lower than elsewhere.

\section{Field measurement procedure}

\subsection{Data collection}

More than 2000 objects were measured, focusing on shear bands and shear domains, during two field data collection campaigns. Measurements were performed as shown on Figure $6 \mathrm{a}$ and, for the sake of consistency, by the same team for all outcrops.

$\mathrm{C}_{3}{ }^{\prime}$ shear band length, width, and angle with the adjacent S2 schistosity $(\alpha)$ were systematically measured for sixteen outcrops (Table 1; Fig. 6a). The surface occupancy of the shear bands, referred to below as the shear band density (SBD, which varies between 0 and 1), is defined as:

$$
\delta=\mathrm{SBD}=\sum_{i=1}^{n} \frac{w_{i} \cdot L_{i}^{c}}{S}
$$

where $\mathrm{w}_{\mathrm{i}}$ and $\mathrm{L}_{\mathrm{i}}^{\mathrm{c}}$ represent the width and length of each shear band, respectively, and $\mathrm{S}$ represents the delineated surface area over which shear bands were exhaustively measured. Given the increase in shear band density, smaller and smaller S surfaces were measured when approaching the detachment (Table 1).

Areas were delineated by crosses (Figs. 6a,b), major shear bands were numbered and then all the minor shear bands in between were measured. The total surface, $\mathrm{S}$, was estimated in 
the laboratory by image analysis of field photographs taken perpendicular to the outcrop, so that results are fraught with a maximum $5 \%$ uncertainty.

Shear bands are commonly linear or slightly curvilinear, so that their length can be measured easily and reliably. Shear band width was taken as the maximum width along the shear band (as in Schrank et al., 2008), but is apparently almost constant along strike. Width was measured only for sites $1-4$, during our first campaign. Indeed, measuring widths is far less reliable than lengths, since the width of the shear bands can be widened artificially by vegetation or surface weathering (especially for sites $4 \mathrm{AB}$, where both shear bands and the schistosity are verticalized). Another potential bias comes from very small shear bands, for which measurement uncertainty is huge: a default shear band width of $1 \mathrm{~mm}$ was systematically given to them.

Several corrections were thus applied to derive a 'best', plausible thickness-length relationship (see below and the inset of Fig.7b). Average results by site and zone (I to V) are shown in Table 1. In order to minimize the impact of this correction, we finally choose to calculate SBD using the average of all corrections performed (see below).

Shear domains (which, at the cm-scale, can be thought of 'microlithons') were measured with a particular care to avoid welded veins. These shear domains represent areas, generally sandwiched between the $\mathrm{C} 3$ ' shear bands, where S2 is deflected and boudinaged in places (Fig. 6a). They can be approximated by roughly elliptical, lens-shaped domains, with long $\left(\mathrm{L}^{\mathrm{p}}{ }_{\mathrm{i}}\right)$ and short $\left(\mathrm{l}_{\mathrm{i}}\right)$ axes, allowing determination of their aspect ratio $\left(\mathrm{R}=\mathrm{L}_{\mathrm{i}}^{\mathrm{p}} / \mathrm{l}_{\mathrm{i}}\right)$. They can generally be thought of belonging to C-S structures, but can also correspond to boudinaged sections of schistosed domains lacking shear bands.

\subsection{Internal consistency}


Our measurement procedure thus provides a way to evaluate the consistency of the measurements since not all of them are independent, as shown in Fig. 6d-f. One should expect the following correlations:

(1) There is an obvious relationship between the average length of the shear bands $\left(\overline{L^{c}}\right)$ and the average shear domain length $\left(\overline{L^{p}}\right): \overline{L^{p}}=\overline{L^{c}} \cdot \cos \alpha$ (Fig. 6d).

(2) Similarly, the shear band density (SBD) can be predicted to vary as a function of $\frac{1}{\overline{L^{c}}}$ (or $\frac{1}{L^{p}}$, Fig. 6e) since:

$\delta=\mathrm{SBD}=\sum_{i=1}^{n} \frac{w_{i} \cdot L_{i}^{c}}{S}=\bar{n} \cdot \bar{w} \cdot \overline{L^{c}}$, where $\bar{n}, \bar{w}, \overline{L^{c}}$ are the average number, width and length of the shear bands, respectively.

Note that $\bar{n}$ can be expressed as $\bar{n}=\frac{S}{\overline{L^{c}} \cdot \bar{d}}$, where $\bar{d}$ is the average spacing between the shear bands, which is equal to $\overline{L^{p}} \cdot \sin \alpha$ (Fig. 6e).

Finally, substituting for $\overline{L^{p}}=\overline{L^{c}} \cdot \cos \alpha$, the shear band density rewrites as:

$$
\delta=\operatorname{SBD}=\frac{\bar{w}}{\overline{L^{c}} \cdot \cos \alpha \cdot \sin \alpha} \text {, and is therefore inversely proportional to } \frac{1}{\overline{L^{c}}} \text {. }
$$

(3) Given our geometrical description, $\alpha$ can be approximated by $\alpha^{*}$ through the following relationship (Fig. $6 \mathrm{f}$ ): $\alpha^{*}=\arctan \mathrm{x} / \mathrm{R}$, where $\mathrm{x}$ is proportional to the shear domain width, $\bar{l}$. Note that the value of $\alpha$ should decrease with increasing R (i.e., flatter shape ratios; as in Ramsay and Graham, 1970), and that $x \geq 1 / 2$.

\section{Discussion}




\subsection{Major trends of the dataset}

The distributions of shear band length and of $\mathrm{C}_{3}{ }^{\prime}-\mathrm{S} 2$ angles are shown in figure $7 \mathrm{a}$ for zones II, III and IV. Small shear bands (length $<5 \mathrm{~cm}$ ) are only found in zone IV and intermediate ones $(5-25 \mathrm{~cm})$ are preferentially represented in zone III. $\mathrm{C}_{3}{ }^{\prime}-\mathrm{S} 2$ angles give average values for zones IV, III and II, respectively, of $28.8^{\circ}$ (thus close to the $29^{\circ}$ reported by Platt and Vissers, 1980 on 75 measurements), $23.9^{\circ}$ and $27.1^{\circ}$. These angular values show a strong dispersion, however, with several peaks (zone IV) or none (zones II and III). All three zones evidence a common peak near $33 \pm 2^{\circ}$, but this peak is mostly apparent for zone IV (Fig. 7a).

We focus in the following on average values per site (Table 1). The evolution of the shear band density (SBD) is shown in figure $7 \mathrm{~b}$. Our data shows (1) that SBD values are comparable for sites taken next to each other and (2) reveals a clear trend of increasing SBD when nearing the detachment (whether considering raw data or the average of all corrections performed for shear band width). While the trend is unambiguous, the correlations vary strongly, however, depending on the type of correction chosen for the relationship between shear band width and length (inset, Fig. 7b). The data with the average correction is best fitted by an exponential curve (or, at least at distances $<150 \mathrm{~m}$ from the contact, by a cubic polynomial; Fig. 7b):

$$
\mathrm{SBD}=12.5^{*} \exp ^{-0.01 \mathrm{~d}}+0.55
$$

where $\mathrm{d}$ is the distance expressed in meters.

A marked difference is observed for sites 5, which correspond to significantly more quartz-rich PermoTriassic protoliths and fall off the trend to lower SBD values (Table 1). 
The evolution of the dimension of the shear domains is presented in Figure 8. There is a decrease of shear domain dimensions: the closer to the detachment the smaller the ellipses, whether considering median, minimum or maximum values (Fig. 8a-c). No difference, this time, is observed for sites 5. Despite some scatter in the measurements, the regression fit for $\overline{L^{p}}$ values is close to the expected value $\overline{L^{c}} \cdot \cos \alpha$ (Fig. 9a). Figure 9b further demonstrates the consistency of our measurements by showing the inverse correlation between SBD and $\frac{1}{\overline{L^{c}}}\left(\right.$ or $\left.\frac{1}{\overline{L^{p}}}\right)$

Other variations in aspect ratio of the shear domains $(\mathrm{R})$ and $\mathrm{C}_{3^{\prime}}-\mathrm{S} 2$ angles are shown in Fig. 10. There are strong variations in $\mathrm{R}$ as a function of the distance to the detachment (Fig. 10a). This is also best seen in the log-log plot by zone (Fig. 10a, inset). One could either interpret figure 10a as an overall decrease of the $\mathrm{R}$ value with increasing strain (when getting closer to the contact), with some sites falling off the trend (the oscillation being perhaps due to subtle protolith changes), or as no trend at all. More data are clearly needed. In any case, there is likely one outlier value (site $3 \mathrm{~B}$, which is actually more quartz-rich).

There is a general increase in the $\mathrm{C}_{3}{ }^{\prime}-\mathrm{S} 2$ angle values, $\alpha$, when approaching the contact, across zones I to V (Fig. 10b). One exception is zone II, which in addition shows a strong scatter. As expected, $\alpha$ decreases with increasing R (Fig. 10c).

Figure $10 \mathrm{c}$ also shows that the dependency of $\alpha$ to $\mathrm{R}$ can be roughly fitted by an Arctan function, as suggested in figure $6 \mathrm{f}$. Values of $\alpha^{*}$ were thus calculated by iteration for several values of $\mathrm{x}$ (Fig. 6f) so as to minimize the difference between $\alpha$ and $\alpha^{*}$ for all sites. The best fit (Figs. $10 \mathrm{~b}, \mathrm{c}$ ) is found for $\mathrm{x}=0.84$. Comparison between the two values for each site also allows to see which ones are rounder than the average $\left(\alpha>\alpha^{*}\right.$; e.g., sites 4 and 3B; Figs. $10 \mathrm{~b}, \mathrm{c})$, or flatter $\left(\alpha<\alpha^{*}\right.$; e.g., sites 1 and "2-3"). Finally, we note that our values for $\alpha$ and $\mathrm{R}$ 
plot in the field defined as simple shear by Marques et al. (2007), which confirms our earlier statement that the D3 event is dominated by deformation along the Filabres shear zone.

\subsection{Increase of strain intensity towards the contact}

This study demonstrates that, for a strongly anisotropic metapelitic material, there are clear correlations as a function of the distance to the detachment of (1) the shear band density (SBD; Fig. 7) and of (2) the characteristic size of the shear band domains (Fig. 8). This is further supported by the internal consistency of our measurements, as shown by the correlations between Lc and Lp (Fig. 9a), between SBD and $\frac{1}{\overline{L^{c}}}$ (Fig. 9b), or by the correlation between $\alpha_{\mathrm{C}-\mathrm{S}}$ and R (Fig. 10b,c). Contrary to the deformation of homogeneous, isotropic protoliths such as granites (e.g., Dutruge and Burg, 1997; their figure 7), no periodicity in shear band development was recognized away from the detachment itself (nor away from the larger, individual shear bands measured in the various sites).

This densification of the deformation is schematically depicted in figure 11a: idealized boxes for each zone (I to V) emphasize the trend documented in this study. In the absence of larger, $\mathrm{km}$ - or hm-scale deformation patterns formed during D3 on the one hand, and in the absence of other modes of internal deformation of the rock on the other hand (e.g., obvious crystalline creep evidenced by quartz ribbons, strong boudinage), this SBD pattern (Fig. 7b) can thus be taken as reflecting the overall finite strain for a given outcrop, hereafter noted $\gamma^{*}$ (Fig. 11a).

It is therefore possible to derive an empirical law based on SBD (i.e., equation 1) for the shear strain gradient across the nappe stack. This is consistent with the conclusions of Platt et al. (1984) on the existence of a gradient away from the FSZ detachment, and may in turn, in 
principle, be used to evaluate the distance to the contact. This exponential dependency recalls the one reported for the Pinet laccolith, Southern France, by Dutruge and Burg (1997), or recent correlations found in fault damage zones (e.g., Mitchell and Faulkner, 2009). One should keep in mind, however, that the exact dependency of SBD with the distance to the detachment depends on the relationship between shear band width and length (Fig. 7b, inset).

Figure $11 \mathrm{~b}$ shows schematically how the densification of shear bands, as observed in our study area (Figs. 5, 6, 11a) will favor the relative displacement on numerous shear planes and thereby induce an increase in the overall finite shear strain $\gamma^{*}$ (despite an increase of $\alpha$ when appreaching the Note, however, that if significant volume loss and mass transfer take place near the contact, this contrast in $\gamma^{*}$ may not be so important since for the same apparent angle $\alpha, \gamma^{*}$ will in fact be less in that case (Fig. 11c; Burg and Laurent, 1978).

\subsection{Distributed shear gradient or progressive strain localization with time?}

We critically discuss below two distinct, possible interpretations of our dataset (Fig. 12), which can be viewed as end-member situations:

(1) one in which shear bands are assumed to form coevally through time in the whole NF complex and thus represent the response of these metapelites to a steady-state deformation and strain rate gradient through time and space (scenario 1; Fig. 12a; for a discussion on mechanical steady state in shear zones, see Handy et al., 2007). If these assumptions hold, the shear bands we measured relate to one single tectonic event (D3 stage) and the SBD and our correlations can be interpreted in terms of cumulative strain $\left(\gamma^{*}\right)$ and/or variations in deformation rates. The spacing of the shear bands could be internally (eg, by the strongly 
anisotropic, phyllosilicate-rich rheology; see Le Pourhiet et al., subm.) or externally controlled (i.e., by the size and morphology of the greenschist-facies veins).

(2) one in which this SBD increase towards the contact in fact corresponds to a diachronous, progressive localization of deformation (scenario 2, Fig. 12b): the deformation (and strain rate) gradient changed with time so that more and more deformation was taken up near the contact and portions located beyond a given distance/depth from it at $t_{n}$ were no longer deformed during the next deformation step $t_{n+1}$ (see the black dots in Fig. 12b). Such a progressive localization of the deformation can be expected a) from cooling on exhumation (as the P-T-t-deformation history for these rocks suggest: Fig. 2c), b) from a rheological weakening near the contact (for example in response to enhanced deformation and fluid circulation) and/or c) from a change of boundary conditions and deformation rates. In any case, scenario 2 implies that the overall width of the Filabres shear zone effectively decreased with time as the rocks were progressively exhumed and deformation became focused in a narrower deformation band/volume (as in type II shear zones of Means, 1995; see also Herwegh et al., 2008). The comparison between the $\gamma^{*}$ values recorded at various distances away from the contact (i.e., finite deformation as deduced from SBD; Fig. 11a) cannot be used as a straightforward rheological proxy in this case, since deformation during the D3 stage did not span the same time interval at the various sites.

In order to assess which scenario prevails, radiometric ${ }^{40} \mathrm{Ar} /{ }^{39} \mathrm{Ar}$ ages from four PermoTriassic samples of the upper part or the Calar Alto unit (Augier et al., 2005b), located at various distances below the Filabres shear zone, are shown in figure 12c. This plot shows an apparent younging of c. 2 Ma towards the contact in zones IV-V, suggesting that the D3 stage is better recorded close to the contact. This age pattern could suggest that deformation was active later closer to the contact (in support of scenario 2), but could also be explained by the fact that less reequilibration/recrystallization occurred in the less deformed parts, away from 
the contact (as in scenario 1). These two scenarii are in fact not mutually incompatible and deformation patterns may well correspond to a combination of them.

Another indication in support of scenario 2, however, comes from the evolution of angles. At first sight, there is a rather surprising increase of $\alpha$ towards the detachment (and a correlative decrease of R; Figs. 7a, 10a,b), since $\alpha$ should decrease with increasing strain (as shown, in a first approximation, by the following dependency: $\gamma=2 / \tan 2 \alpha$; Ramsay and Graham, 1970). This increase in $\alpha$, best seen in the marked peak at $32^{\circ}$ (Fig. 7a, zone IV), is readily understood, however, if deformation was progressively localised with time, with more brittle deformation near the contact steepening the shear bands in zones IV and V. As the upper part of the nappe stack evolved towards cooler temperature, D3 deformation indeed probably evolved into somewhat more brittle conditions before entering the brittle D4 stage along the FSZ (Augier et al., 2005a; see also Mehl et al., 2005). Increasing angular values towards the contact could also in part be the result of densifying the shear band network and increasing pressure-solution and volume loss (since this would preferentially remove the deflected parts of the S2 near the C3' planes and visually steepen the $\alpha$ angle; Fig. 11c).

The above discussion suggests that scenario 2 (Fig. 12b) prevailed over scenario 1 (Fig. 12a), although their respective contributions can not be precisely assessed at present. If this interpretation is correct, the network of shear bands narrowed with time (e.g., Ben-Zion and Sammis, 2003; as opposed to network widening: e.g., Schrank et al., 2008), indicating that significant mechanical softening occurred near the FSZ detachment.

\section{Concluding remarks}


Our study documents the spatial distribution of extensional crenulation cleavage and shear band networks (Platt, 1979; Platt \& Vissers, 1980; Carreras, 2001; Fusseis et al., 2006) formed during a single, greenschist facies deformation episode (D3) below a regional-scale detachment (i.e., the Filabres shear zone; Platt et al., 1984; García-Dueñas et al., 1988). Shear band density (SBD), as well as the shear angles and the size of shear domains, in these strongly anisotropic, homogeneous and mechanically weak metapelites, all evidence clear trends as a function of the distance to this major contact. In particular, SBD shows an exponential decrease away from the contact.

The observed patterns suggest that, at least as a first approximation, SBD is representative of the finite shear strain gradient accompanying the D3 stage ( $\gamma *$, Fig. 11a). Yet, the comparison of tectonic and radiometric age patterns (Fig. 12c), as well as the steepening of $\alpha$ angles near the contact (Fig. 7a, zone IV), suggest that finite deformation was not fully coeval throughout the rock pile. Part of the finite strain gradient $\gamma^{*}$ recovered here is thus probably diachronous and points to a narrowing of the shear band network with time during D3. Our results therefore support the view that deformation got progressively localised with time in the vicinity of the contact (as for type II shear zones of Means, 1995), most likely as a result of temperature decrease on exhumation, as rocks approached the frictional-toviscous transition (Handy et al., 2007; and possibly, near the contact, as a result of a change in deformation rates too; e.g., White et al., 1980). In-depth additional microscopic work and insitu laser dating of specific phyllosilicates (e.g., Fig. 2d; Augier et al., 2005b) is now needed to unravel the rheological evolution of some individual shear bands over time (i.e., with increasing deformation) and determine whether and how they did grow and rotate.

Future research should aim at strengthening these conclusions in other settings and their applicability to similar, mechanically weak rock-types. In principle, this could help constrain the amount of deformation and/or the distance to the contact (which may prove especially 
useful if this contact was later eroded). Microscopic measurements of porphyroblast shape ratios (e.g., Dutruge and Burg, 1997) or grain size reduction (Stipp and Tullis, 2003; Gueydan et al., 2005) could also help constrain deformation mechanisms and how much deformation is taken up, in these very phyllosilicate-rich rocks, by sliding along shear bands v. grain boundary sliding or crystal dislocation creep (e.g., White et al., 1980; Rosenberg and Stünitz, 2003; Song and Ree, 2007). Better assessing the dependency between progressive deformation and shear band formation will, in any case, be an important step towards estimating rheological parameters and strain rates (e.g., Fusseis and Handy, 2008; Jessell et al., 2009) for these critical rocks.

\section{Acknowledgements}

This study was funded through the CNRS/INSU program "Failles, fluides, flux". We are grateful to Laurent Jolivet for insightful discussions at an earlier stage of this project. Nicolas Charles is warmly thanked for helping us model the geometry of the Filabres detachment in 3D. Florian Fusseis and an anonymous reviewer are thanked for thoughtful reviews, and Tom Blenkinsop for useful comments and handling of the manuscript. 


\section{References}

Agard, P., Monié, P., Jolivet, L., Goffé, B., 2002. In situ laser probe 40Ar/39Ar dating of the Schistes Lustrés complex: implications for the exhumation of the Western Alps. Journal of Metamorphic Geology 20, 599-618.

Arbaret, L., Burg, J.P., 2003. Complex flow in lowest crustal, anastomosing mylonites: strain gradients in a Kohistan gabbro, northern Pakistan. Journal of Geophysical Research 108, doi:10.1029/2002JB002295.

Augier, R., Jolivet, L., Robin, C., 2005a. Late Orogenic doming in the eastern Betic Cordilleras: Final exhumation of the Nevado-Filabride complex and its relation to basin genesis. Tectonics 24, doi:10.1029/2004TC001687.

Augier, R., Agard, P., Monié, P., Jolivet, L., Robin, C., Booth-Rea, G., 2005b. P-T-D-t retrograde evolution of the Nevado-Filabride complex (SE Spain) : new insights from in situ 40Ar/39 ages and metamorphic petrology. Journal of Metamorphic Geology 23, 357-381.

Battacharyya, P., Hudleston, P., 2001. Strain in ductile shear zones in the Caledonides of northern Sweden: a three-dimensional puzzle. Journal of Structural Geology 23, 1549-1565.

Ben-Zion, Y., Sammis, C.G., 2003. Characterization of Fault Zones. Pure and Applied Geophysics 160, $677-$ 715.

Berthé, D., Choukroune, P., Jégouzo, P., 1979. Orthogneiss, mylonite and noncoaxial deformation of granite: The example of the South Armorican Shear Zone. Journal of Structural Geology 1, 31- 42.

Burg, J.P., Laurent. 1978. Strain analysis of a shear zone in a granodiorite. Tectonophysics 47, 15-42.

Calvert, A., Sandvol, E., Seber, D., et al.,. 2000. Geodynamic evolution of the lithosphere and upper mantle beneath the Alboran region of the western Mediterranean: constraints from travel time tomography. Journal of Geophysical Research 105, 10871-10898.

Carreras, J., 2001. Zooming on Northern Cap de Creus shear zones. Journal of Structural Geology 23, $1457-$ 1486.

Carreras, J., Czeck, D.M., Druguet, E., Hudleston, P.J., 2010. Structure and development of an anastomosing network of ductile shear zones. Journal of Structural Geology in press.

Choukroune, P., Gapais, D., 1983. Strain pattern in the Aar Granite (Central Alps): orthogneiss developed by bulk inhomogeneous flattening. Journal of Structural Geology 5, 411-418.

Choukroune, P., Gapais, D., Merle, O., 1987. Shear criteria and structural symmetry. Journal of Structural Geology 9, 525-530.

Cobbold, P.R., Ferguson, C.C., 1979. Description and origin of spatial periodicity in tectonic structures: report on a Tectenic Studies Group conference held at Nottingham University, 8 November 1978. Journal of Structural Geology 1, 93-97.

De Jong, K., 1993. The tectono-metamorphic evolution of the Veleta Complex and the development of the contact with the Mulhacen Complex (Betic Zone, SE Spain). Geologie en Mijnbouw 71, 227-237.

Druguet, E., Passchier, C.W., Carreras, J., Victor, P., den Brok, S., 1997. Analysis of a complex high-strain zone at Cap de Creus, Spain. Tectonophysics 280, 31-45.

Dutruge, G., Burg, J.P., 1997. Strain localization in an orthogneiss laccolith (the Pinet Massif, Aveyron, southern France). Tectonophysics 280, 47-60.

Dutruge, G., Burg, J.P., Lapierre, J., 1995. Shear strain analysis and periodicity within shear gradients of metagranite shear zones. Journal of Structural Geology 17, 819-830.

Fusseis, F., Handy, M., 2008. Micromechanisms of shear zone propagation at the brittle-viscous transition. Journal of Structural Geology 30, 1242-1253.

Fusseis, F., Handy, M.R., Schrank, C., 2006. Networking of shear zones at the brittle-to-viscous transition (Cap de Creus, NE Spain). Journal of Structural Geology 28, 1228-1243.

Gapais, D., Bale, R., Choukroune, P., Cobbold, P., Mahjoub. Y., Marquer, D., 1987. Bulk kinematics from shear zone patterns: some field examples. Journal of Structural Geology 9, 635-646.

Garcia-Duenas, V., Balanya, J.C., Martinez-Martinez, J.M., 1992. Miocene extensional detachments in the outcropping basement of the Northern Alboran Basin (Betics) and their tectonic implications. GeoMarine Letters 12, 88-95.

Garcia-Duenas, V., Martinez-Martinez, J.M., Orozco, M., Soto, J., 1988. Plis-nappes, cisillements syn- à post- 
métamorphiques et cisaillements ductiles-fragiles en distension dans les Nevado-Filabrides (Cordillières Bétiques, Espagne). Comptes Rendus de l'Académie des Sciences de Paris 307, 1389-1395.

Gonzalez-Casado, J.M., Casquet, C., Martinez-Martinez, J.M., Garcia-Duenas, V., 1995. Retrograde evolution of quartz segregations from the Dos Picos shear zone in the Nevado-Filabride Complex (Betic chains, Spain). Evidence from fluid inclusions and quartz c-axis fabrics. Geologische Rundschau 84, 175-186.

Grasemann, B., Stuwe, B., Vannay, J.C., 2003. Sense and non-sense of shear in flanking structures. Journal of Structural Geology 25, 19-34.

Gueydan, F., Leroy, Y., Jolivet, L., Agard, P., 2003. Analysis of continental midcrustal strain localization induced by microfracturing and reaction-softening. Journal of Geophysical Research 108, doi:10.1029/2001JB000611.

Gueydan, F., Mehl, C., Parra, T., 2005. Stress-strain rate history of a midcrustal shear one and the onset of brittle deformation inferred from quartz recrystallized grain size. In: Deformation mechanisms, rheology and tectonics (edited by Gapais, D., Brun, J.P.Cobbold, P.) 243. Geological society, 127-142.

Handy, M.R., Brun, J.P., 2004. Seismicity, structure and strength of the continental lithosphere. Earth and Planetary Science Letters 223, 427-441.

Handy, M.R., Hirth, G., Burgmann, R., 2007. Continental fault structure and rheology from the frictionalviscous transition downward. In: Tectonic faults - Agents of Change on a Dynamic Earth (edited by Handy, M.R., Hirth, G.Hovius, N.). MIT Press, Cambridge, Mass., 139 - 182.

Hippertt, J., 1999. Are S-C structures, duplexes and conjugate shear zones different manifestations of the same scale-invariant phenomenon? Journal of Structural Geology 21, 975-984.

Isaaks, E.H., Srivastava, R.M., 1989. Applied Geostatistics. Oxford University Press.

Jessell, M.W., Bons, P.D., Griera, A., Evans, L.A., Wilson, C.J.L., 2009. A tale of two viscosities. Journal of Structural Geology 21, 719-736.

Johnson, C., Harbury, N., Hurford, A.J., 1997. The role of extension in the Miocene denudation of the NevadoFilabride Complex, Betic Cordillera (SE Spain). Tectonics 16, 189-204.

Jolivet, L., Faccenna, C., 2000. Mediterranean extension and the Africa-Eurasia collision. Tectonics 19, 1095 1109.

Jolivet, L., Augier, R., Robin, C., Suc, J.P., Rouchy, J.M., 2006. Lithospheric-scale geodynamic context of the Messinian salinity crisis. Sedimentary geology 188-189, 9-33.

Jolivet, L., Augier, R., Faccenna, C., Negro, F., Rimmele, G., Agard, P., Robin, C., Rossetti, F., Crespo-blanc, A., 2008. Subduction, convergence and the mode of backarc extension in the Mediterranean region. Bulletin de la Société Géologique de France 179, 525-550.

Lafuste, M.L.J., Pavillon, M.J., 1976. Mise en évidence d'Eifélien daté au sein des terrains meétamorphiques des zones internes des Cordillères bétiques. Intéret de ce nouveau repère stratigraphique. Comptes Rendus de l'Académie des Sciences de Paris 283, 1015-1018.

Le Pourhiet, L., Burov, E., Moretti, I., 2004. Rifting through a stack of inhomogeneous thrusts (the dipping pie concept). Tectonics 23, doi: 10.1029/2003TC001584.

Le Pourhiet, L., Huet, B., Agard, P., Labrousse, L., Yao, K., Jolivet, L., Mechanics of Strain Localisation in Foliated Media, insights from numerical modelling. Journal of Structural Geology, submitted.

Marques, F.O., Schmid, D.W., Andersen, T.B., 2007. Applications of inclusion behaviour models to a major shear zone system: The Nordfjord-Sogn Detachment Zone in western Norway. Journal of Structural Geology 29, 1622-1631.

Martinez-Martinez, J.M., Azanon, J.M., 1997. Mode of extensional tectonics in the southeastern Betics (SE Spain). Implications for the tectonic evolution of the peri-Alboran orogenic system. Tectonics 16, 205225.

Martinez-Martinez, J.M., Soto, J.I., Balanya, J.C., 2002. Orthogonal folding of extensional detachments: structure and origin of the Sierra Nevada elongated dome (Betics, SE Spain). Tectonics 21, doi 10.1029/2001TC001283.

Means, W.D., 1995. Shear zones and rock history. Tectonophysics 247, 157-160.

Mehl, C., Jolivet, L., Lacombe, O., 2005. From ductile to brittle: Evolution and localization of deformation below a crustal detachment (Tinos, Cyclades, Greece). Tectonics 24, doi:10.1029/2004TC001767.

Michibayashi, K., Murakami, M., 2007. Development of a shear band cleavage as a result of strain partitioning. Journal of Structural Geology 29, 1070-1082.

Mitchell, T.M., Faulkner, D.R., 2009. The nature and origin of off-fault damage surrounding strike-slip fault zones with a wide range of displacements: A field study from the Atacama fault system, northern Chile. Journal of Structural Geology 31, 802-816.

Passchier, C.W., 1980. Monoclinic model shear zones. Journal of Structural Geology 20, 1121-1137.

Passchier, C.W., 1984. The generation of ductile and brittle shear bands in a low-angle mylonite zone. Journal of Structural Geology 6, 273-281.

Passchier, C.W., 2001. Flanking structures. Journal of Structural Geology 23, 951-962. 
Pennachioni, G., Mancktelow, N.S., 2007. Nucleation and initial growth of a shear zone network within compositionally and structurally heterogeneous granitoids under amphibolite facies conditions. Journal of Structural Geology 29, 1757-1780.

Platt, J., 1979. Extensional crenulation cleavage. Journal of Structural Geology 1, 95.

Platt, J., 1984. Secondary cleavages in ductile shear zones. Journal of Structural Geology 6, 439-442.

Platt, J., Berhmann, J.H., Martinez-Martinez, J.M., Vissers, R.L.M., 1984. A zone of mylonite and related ductile deformation beneath the Alpujarride nappe complex, Betic cordilleras, S. Spain. Geologische Rundschau 73, 773-785.

Platt, J.P., Soto, J. I., Whitehouse, M. J., Hurford, A. J. \&, Kelley, S.P., 1998. Thermal Evolution, Rate of Exhumation, and Tectonic Significance of Metamorphic Rocks from the Floor of the Alboran Extensional Basin, Western Mediterranean. Tectonics 17, 671-689.

Platt, J.P., Vissers, R.L.M., 1980. Extensional structures in anisotropic rocks. Journal of Structural Geology 2 , 397-410.

Platt, J.P., Vissers, R.L.M., 1989. Extensional collapse of thickened continental lithosphere: a working hypothesis for the Alboran Sea and Gibraltar arc. Geology 17, 540-543.

Ramsay, J.G., 1980. Shear zone geometry: a review. Journal of Structural Geology 2, 83-99.

Ramsay, J.G., Graham, R.H., 1970. Strain variation in shear belts. Canadian Journal of Earth Sciences 7, 786813.

Ramsay, J.G., Huber, M.I., 1983. The techniques of modern structural geology. Academic Press.

Rosenberg, C.L., Stunitz, H., 2003. Deformation and recrystaliization of plagioclase along a temperature gradient: an example from the Bergell tonalite. Journal of Structural Geology 25, 389-408.

Royden, L.H., 1993. The tectonic expression of slab pull at continental convergent boundaries. Tectonics 12 , 303-325.

Sassier, C., Leloup, P.H., Rubatto, D., Galland, O., Yue, Y., Lin, D., 2009. Direct measurement of strain rates in ductile shear zones: A new method based on syntectonic dikes. Journal of Geophysical Research 114, doi:10.1029/2008JB005597.

Scholz, C.H., 2007. Fault mechanics. In: Treatise on Geophysics (edited by Schubert, G.) Volume 6. Crust and Lithosphere Dynamics. Elsevier, 441-483.

Schrank, C.E., Handy, M.R., Fusseis, F., 2008. Multiscaling of shear zones and the evolution of the brittle-toviscous transition in continental crust. Journal of Geophysical Research 113, doi: $10.1029 / 2006$ JB004833.

Shea, W.T., Kronenberg, A.K., 1993. Strength and anisotropy of foliated rocks with varied mica contents. Journal of Structural Geology 15, 1097-1121.

Song, W.J., Ree, J.H., 2007. Effect of mica on the grain size of dynamically recrystallized quartz in a quartzemuscovite mylonite. Journal of Structural Geology 29, 1872-1881.

Stipp, M., Stunitz, H., Heilbronner, R., Schmid, S.M., 2002. The Eastern Tonale fault zone: a 'natural laboratory' for crystal plastic deformation of quartz over a temperature range from 250 to $700^{\circ} \mathrm{C}$. Journal of Structural Geology 24, 1861-1884.

Tikoff, B., Fossen, H., 1993. Simultaneous pure and simple shear: the unifying deformation matrix. Tectonophysics 217, 267-283.

Vissers, R.L.M., Platt, J.P., Van der Wal, D., 1995. Late orogenic extension of the Betic Cordillera and the Alboran domain: A lithospheric view. Tectonics 14, 786-803. 


\section{Figure captions}

\section{Table 1}

Summary of average values for measurements performed on the field, listed by site and zone (first two columns). The distance to the detachment is indicated (Dist.).

Different estimates of the average shear band density per site (SBD), taken here as the surface occupancy of a given area (column 'Surf.'), are given here (and in Fig. 7b): $\mathrm{SBD}^{\circ}$ corresponds to raw data, whereas SBD1-3 are corrected by a length-width relationship (see text and the inset of Fig. 7b). 'average' is the average of these four estimates.

Note that the number of measurements for shear bands (nSB), shear domains (nSD), uncertainties related on the distance to the detachment (+-d), the surface considered on each site (Surf.) and GPS coordinates are given in the far right.

Other abbreviations: alpha correspond to measured angles between C3' and S2 given in degrees (alpha* corresponds to a fitted value: see text and Fig. $6 \mathrm{f}$ for details); Lmed, mean: median and mean values for shear band length; Ratios: R: shape ratio of shear band domains (L/l= length over width); Sigm: standard deviation of $\mathrm{R}$ values.

\section{Fig. 1}

Location of the studied area:

(a) at the western termination of the Alpine belt, within the Betic-Rif orogen

(b) in the Nevado-Filabride complex of the internal zones of the Betic Cordilleras, east of the Sierra Nevada.

(c) NW of the Mio-Pliocene Tabernas sedimentary basin. Boxes correspond to maps shown in Fig. 3a. Stretching lineations associated with the exhumation of the Nevado-Filabride and Alpujarride units are compiled from the litterature (see references in Augier et al., 2005a). Permo-Triassic protoliths of the Nevado-Filabride units previously dated by Augier et al. (2005b) are also shown: samples 9,7,4 and 8 are located at increasing distances from the contact.

\section{Fig. 2}

(a) Location of C3' shear bands (or extensional crenulation cleavage; Platt and Vissers, 1980; Plat, 1984) in the nappe stack and aim of this study

(b) Schematic meter-scale tectonic patterns showing the evolution (through time and space) of deformation: the dominant, flat-lying schistosity is transposed into a new planar anisotropy defined by $\mathrm{C} 3$ ' shear bands.

(c) P-T-time-deformation constraints for these Nevado-Filabride units (after Augier et al., 2005b)

(d) Radiometric age constraints for D2 (S2) and D3 (C3') deformation events, as seen from samples CA9 (located in Fig. 1c; Augier et al., 2005b)

Fig. 3 
(a-b) Kilometer-scale patterns of the $\mathrm{S} 2$ foliation and $\mathrm{D}(2-) 3$ stretching lineations. Sites (given as numbers) were measurements were performed are indicated (see also Table 1). White lines: interpolated isohypse distances to the main contact (see text for details)

(c) Schematic section showing how distances to the main tectonic contact (i.e., the detachment separating the Alpujarride and Nevado-Filabride complexes) were estimated. See $\S 3.1$ for details.

(d) View across the Filabres ridge looking north, on the road between Tabernas and Velefique, showing the location of the XZ exposures selected for measurements.

\section{Fig. 4}

(a) View across the Filabres detachment in the southern part of the study area (sites 4A,B; Fig. 3a). The Filabres detachment is visible below the basal unconformity of the Mio-Pliocene Tabernas basin (see also Platt et al., 1984, Fig. 6). Sites 4a,B are located $50 \mathrm{~m}$ below the detachment. Sample CA9 (Figs. 1,12) was collected in the upper, Permo-Triassic part (PTr) of the Nevado-Filabride unit. ALP: Alpujarride unit; NF: Nevado-Filabride unit; Pz: Paleozoic.

(b-h) Outcrop-scale views of deformation patterns across XZ sections.

(b-c) Typical aspect of shear bands around sites 4A,B: penetrative shear bands, or extensional crenulation cleavage crop out over distances several tens of meter thick.

(d-e) Distributed, cm-scale shear bands deflecting and partly cutting across the earlier S2 schistosity in sites 4A and $\mathrm{B}$, respectively.

(f) Microscopic, thin-section view (in plane polarized light) of a representative sample from site 4B. In addition to the shear bands, note the presence of boudinaged chloritoid crystals, pressure shadows around garnet and highly deformed quartz ribbons.

(g-h) Distributed, cm-scale shear bands in site 4C.

\section{Fig. 5}

Outcrop-scale views of deformation patterns across $\mathrm{XZ}$ sections at increasing distances from the Filabres detachment (sites 3, 2 and 1, respectively). Arrows point to some of the markers used to delineate the surface area (white crosses) and label larger shear bands (white dots).

(a) Site $3 \mathrm{~A}$, cross-cut by a few meter-long and predominantly $20-40 \mathrm{~cm}$ long shear bands: see the drawing of Fig. $6 b$.

(b) Meter-scale view of site 3B. This site is slightly more heterogeneous than site 3A in terms of lithology: Paleozoic metapelites with more quartz-rich portions crop out as stretched limbs of larger-scale recumbent folds in herited from stages D1 (and partly D2).

(c-e) Pictures of sites 2. Note the presence of a somewhat larger, yet more localized shear band network in site $2 \mathrm{C}$.

(f) Site 1A: only few D3 shear bands are recognized.

\section{Fig. 6}

(a) Measurement strategy: $\alpha, 1, \mathrm{~L}^{\mathrm{c}}$ and $\mathrm{L}^{\mathrm{p}}$ were systematically measured on the field (average values are given in Table 1; all measures are available on request). Thicknesses ( $t$ ) were only measured for sites 1-4. The shear band 
density, $\delta$, is taken as the surface occupancy (i.e., lengths times thicknesses) of the shear bands over the measured area.

(b) Sketch illustrating how measurements were performed, after carefully drawing to scale the outcrop and numbering the major shear bands.

(c) Close-up view of the upper right corner of site 3A. Garnet and chloritoid crystals are readily visible (compare with Fig. 4e from site 4B).

(d-f) Internal consistency in the measurements due to geometrical relationships. See text (§ 4.2) for details

\section{Fig. 7}

(a) Histograms of the measurements of shear band lengths and C3'-S2 angles, grouped by zone. See text for discussion.

(b) Plots of shear band density as a function of the distance to the detachment, for different width-length relationships (see Table 1 and inset). The average of all values (grey squares) is fitted by an exponential or a power law function (at least for zones II-IV; see text). Inset: width-length relationship for shear bands from sites 1-4. A general trend is noticeable but there is considerable scatter.

\section{Fig. 8}

Plot of median, minimum and maximum lengths of shear domains, respectively (Med., Min., Max.), as a function of the distance to the detachment.

\section{Fig. 9}

(a) Plot of median lengths of shear bands and shear domains, respectively (Lc, Lp), as a function of the distance to the detachment. Despite the scattering, regression lines for each set are shown. The dotted line, which corresponds to the regression line for Lc times the cosinus of the average angular value of all sites, lies close to the regression line for Lp as expected (Fig. 6d).

(b) Plot of the average shear band density (Fig. 7b) as a function of median lengths of shear bands and shear domains (Lc, Lp). As expected, this relationship trends as an hyperbolic function (see Fig. 6e).

\section{Fig. 10}

(a) Evolution of average shape ratio values, R, per site as a function of the distance to the detachement. Possible trends are indicated, yet most values plot between 2.9 and 3.4. Table 1 also points to large deviations. Inset: further insights are provided by variations per zone.

(b) Evolution of average angular values per site $(\alpha)$ as a function of the distance to the detachement. For $\alpha^{*}$, see Figs. 10c and 6f.

(c) Evolution of average angular values per site $(\alpha)$ versus average shape ratio values (R). Values of $\alpha^{*}$ ( $\alpha^{*}=\arctan x /$, Fig. 6f) were calculated by iteration for several values of $x$ (Fig. 6f) so as to minimize the difference between $\alpha$ and $\alpha^{*}$ for all sites.

Fig. 11 
(a) Summary of observations: schematic sketches depicting deformation patterns throughout zones I-V (boxes) and evolution of the shear band density (SBD) as a function of the distance to the main tectonic contact (Fig. 7b). This SBD pattern reflects the finite shear strain $\left(\gamma^{*}\right)$ for a given outcrop for the D3 stage. See text for discussion. (b) Simple sketches illustrating how the densification of shear band network will result, through the cumulative displacement on each shear band (and even if $\alpha$ is equal in both cases), in an increase of the finite shear strain $\gamma^{*}$. Line markers $\mathrm{AB}$ (are taken as representing the initial S2 schistosity) are deflected to $\mathrm{A}^{\prime} \mathrm{B}^{\prime}$ for reference.

(c) In the case of simple shear accompanied by significant some volume loss, the increase in finite shear strain $\left(\gamma^{*}\right)$ seen in Fig. $11 \mathrm{~b}$ will be reduced.

\section{Fig. 12}

Two totally different interpretations may account for the evolution of shear band densities (SBD) throughout the Nevado-Filabride units shown in Figs. 7b and 11a:

(a) shear bands formed coevally through time in the whole nappe stack and thus represent the response of this nappe stack to a constant deformation gradient through time and space

(b) the SBD increase towards the contact corresponds to a diachronous, progressive localization of deformation, as a result of cooling on exhumation and/or of rheological weakening near the contact (or a change in deformation velocities).

(c) Plot of radiometric ${ }^{40} \mathrm{Ar} /{ }^{39} \mathrm{Ar}$ ages from four Permo-Triassic samples of the upper part or the Calar Alto unit, located at various distances below the Filabres shear zone (see Fig. 1c; Augier et al., 2005). This plot shows that the D3 stage is better recorded close to the contact, in what corresponds to zones IV-V. This age pattern indicates that deformation was active later closer to the contact, and thus rather supports scenario 2 (Fig. 12b). See text for details. 
Fig. 1

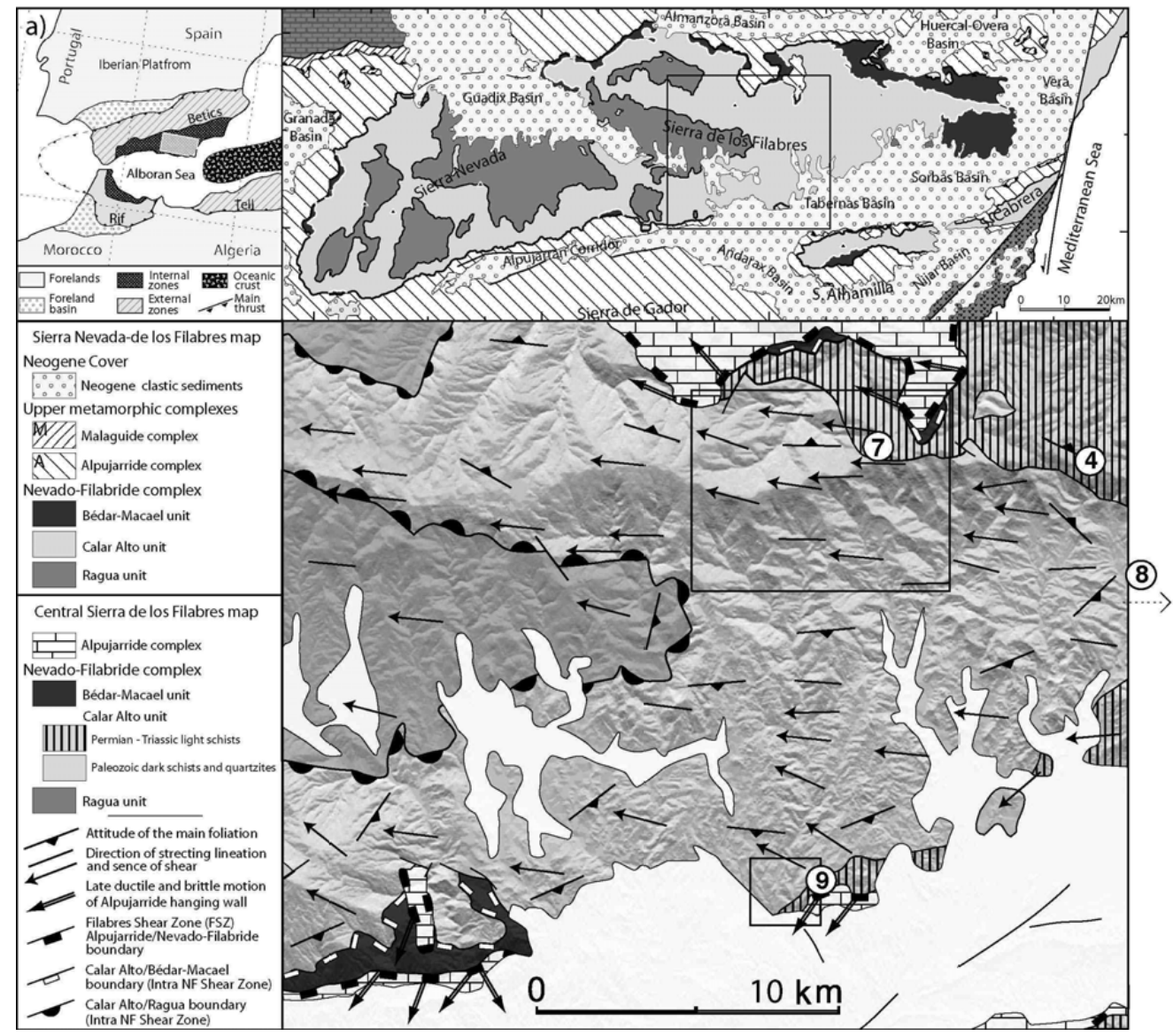


Fig. 2

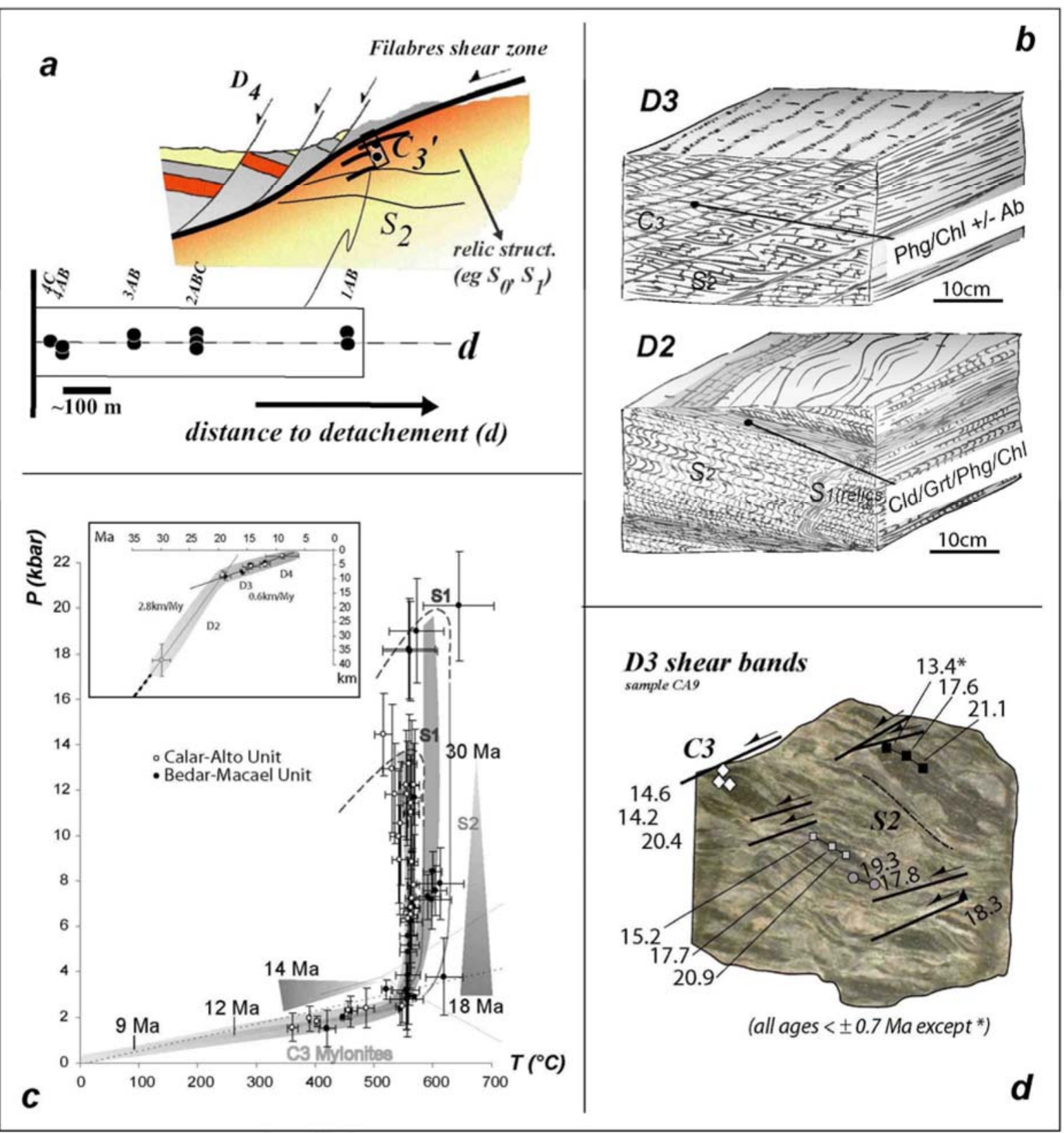


Fig. 3
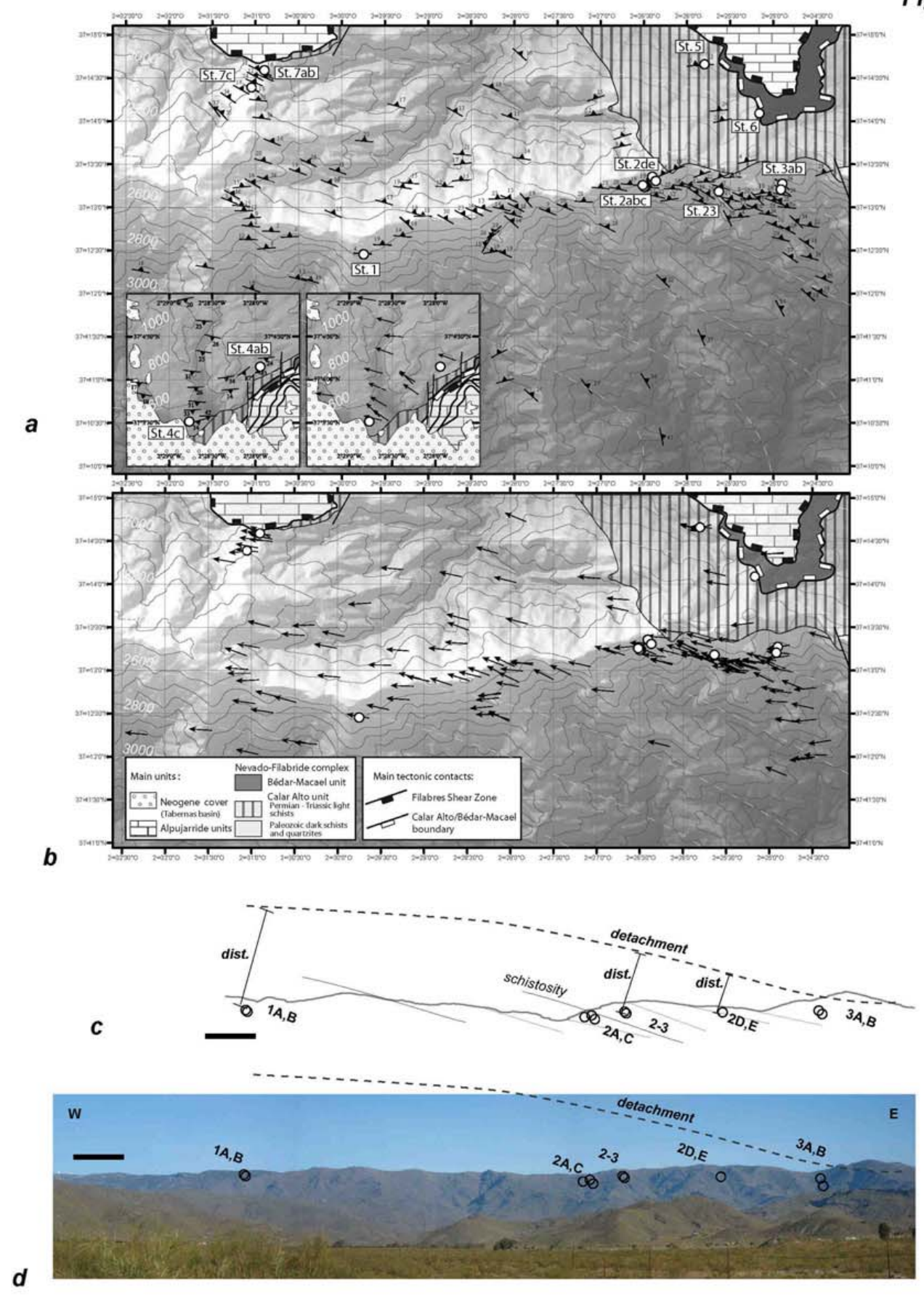
Fig. 4
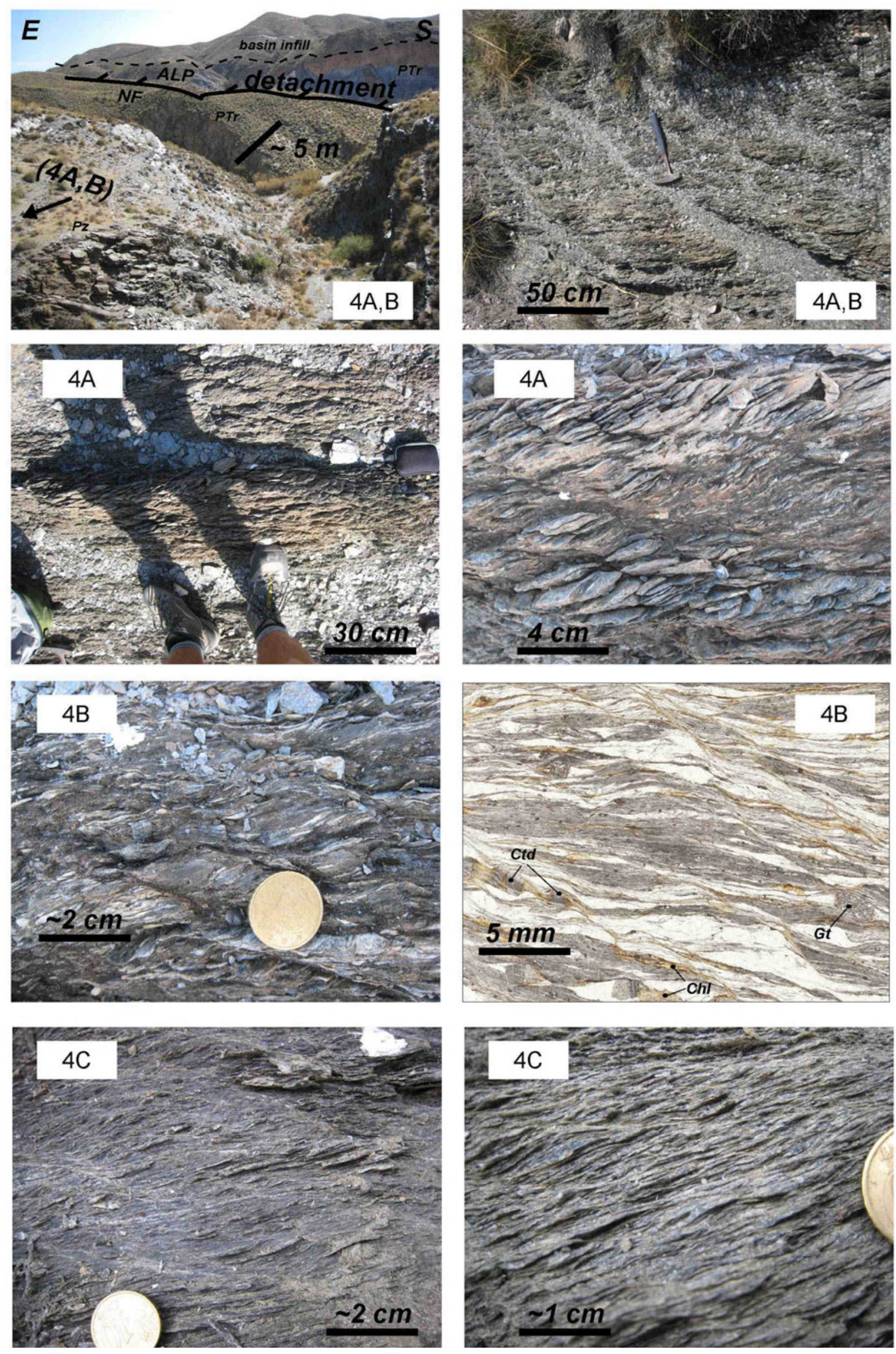
Fig. 5
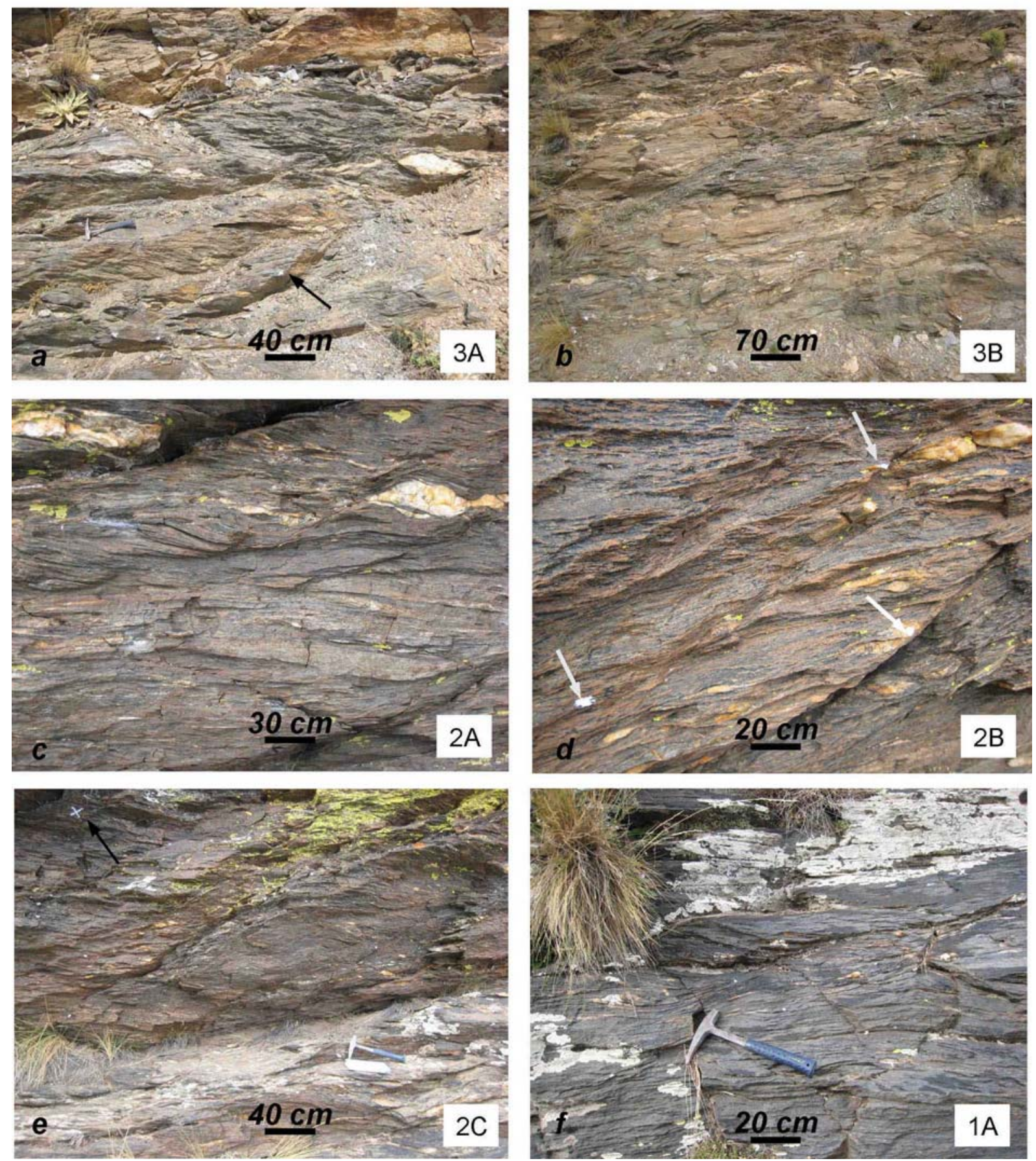
Fig. 6
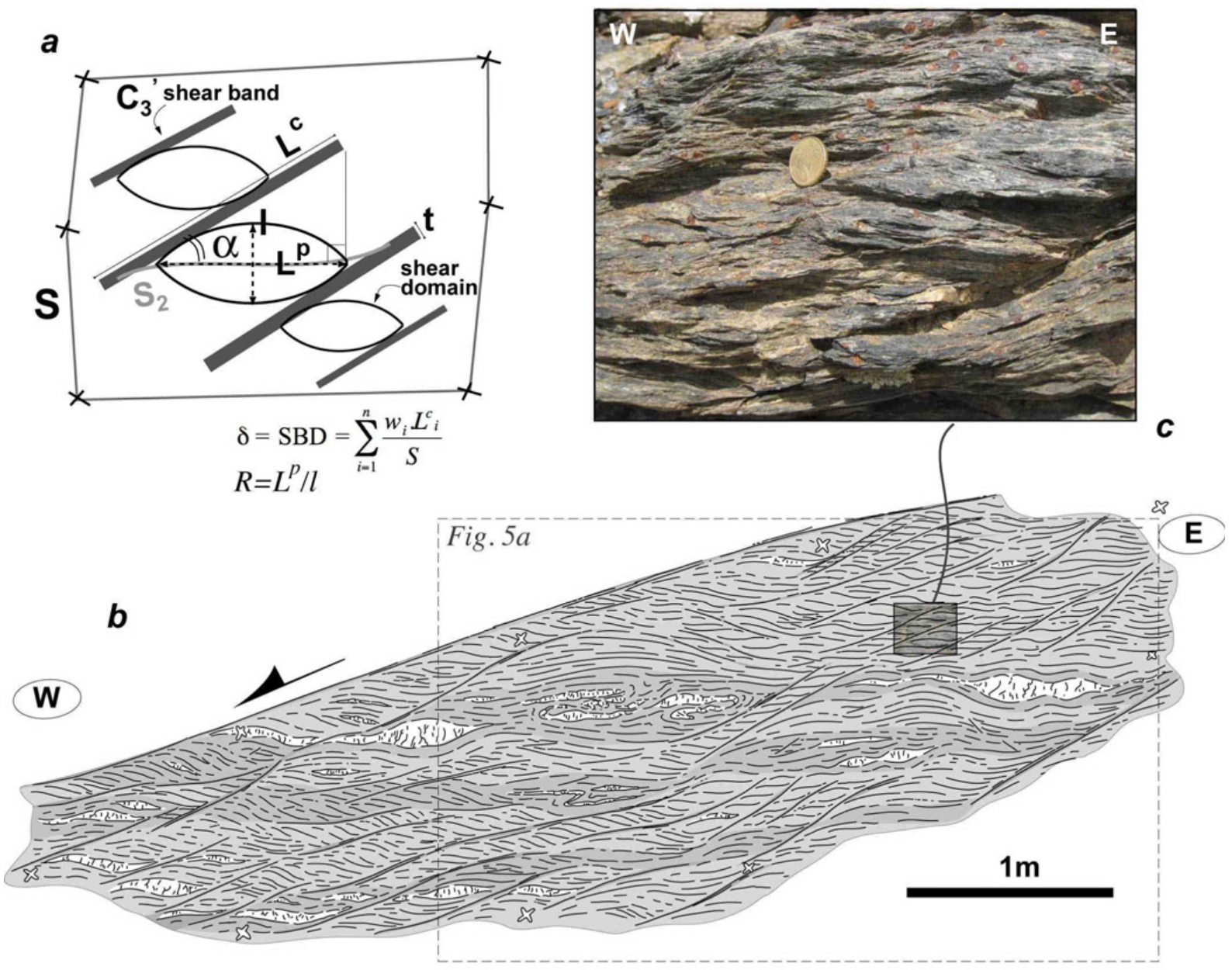

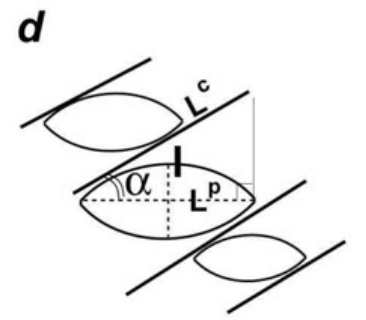

$\mathrm{L}^{\mathrm{p}} \sim \mathrm{L}^{\mathrm{C}} \cdot \cos \alpha$ e

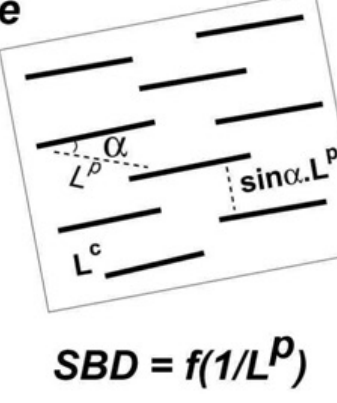

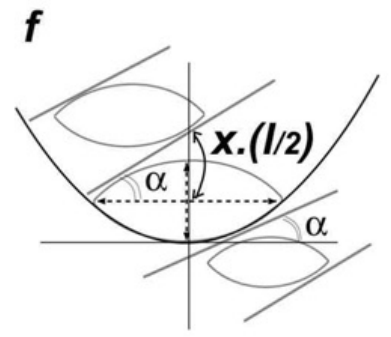

$\alpha \sim \arctan \mathbf{x} / \mathbf{R}\left(=\alpha^{\star}\right)$ 
Fig. $7 a$

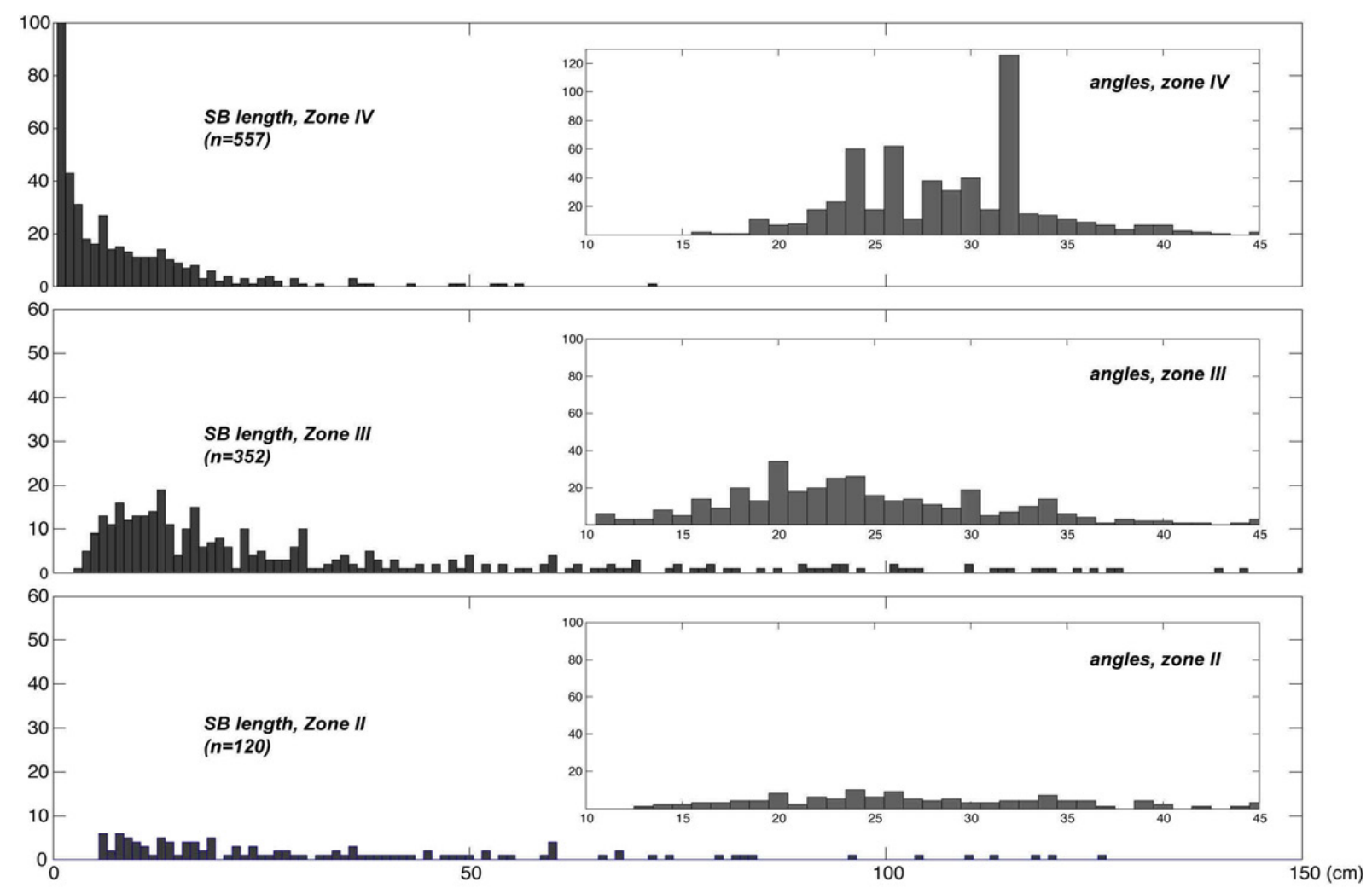


Fig. $7 b$

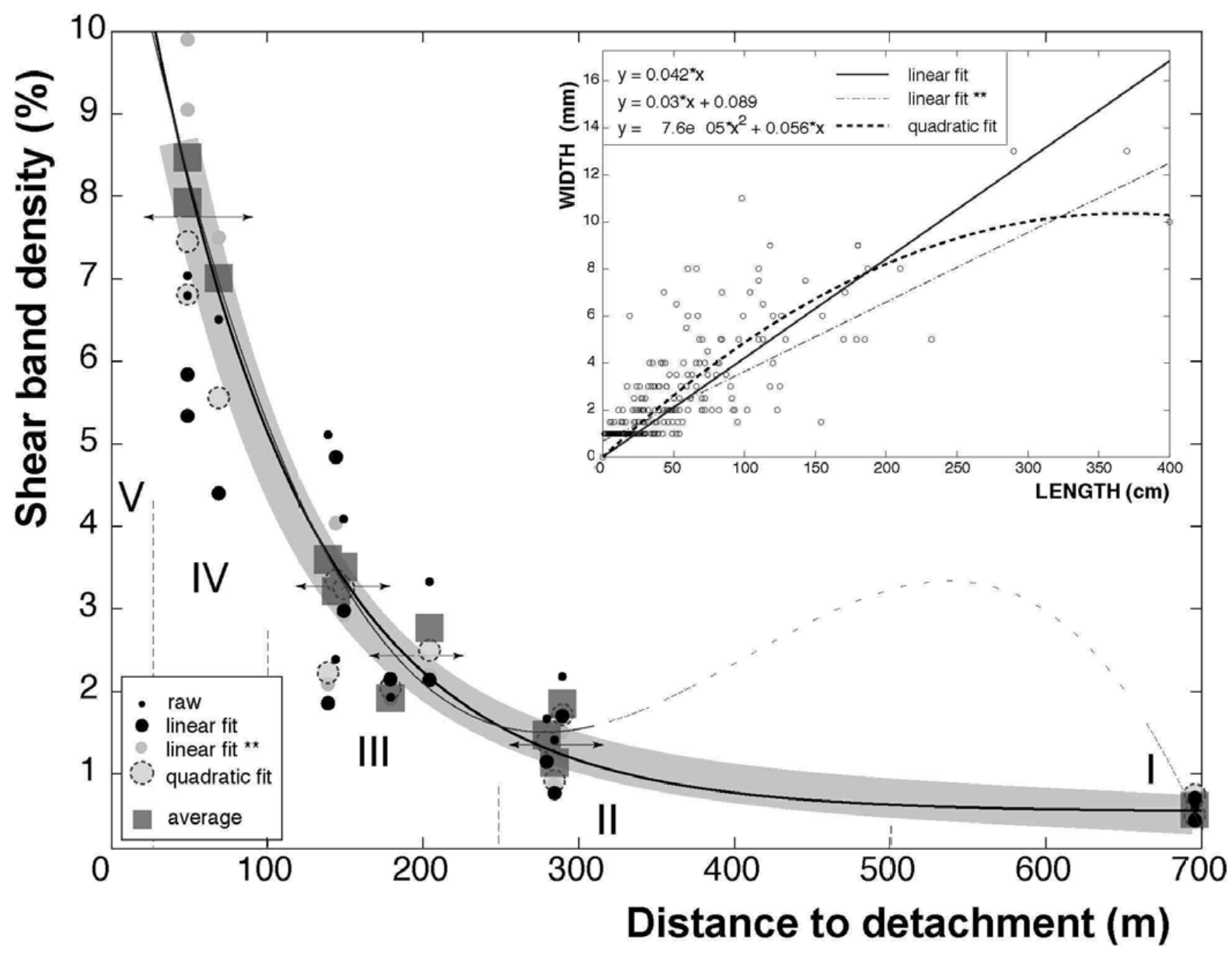


Long axis $(\mathrm{cm})$

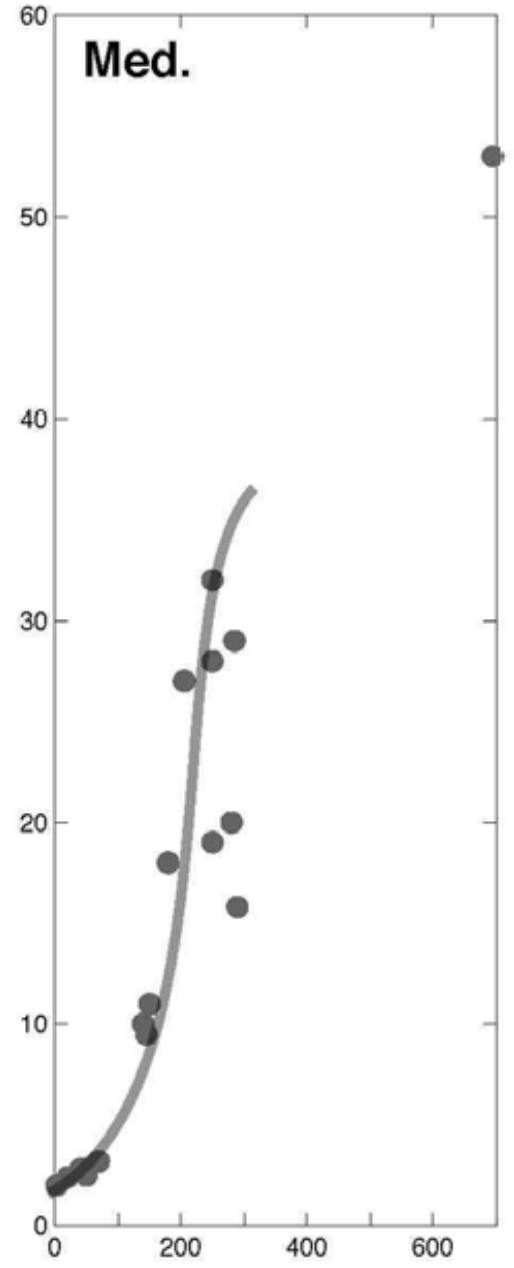

Fig. 8
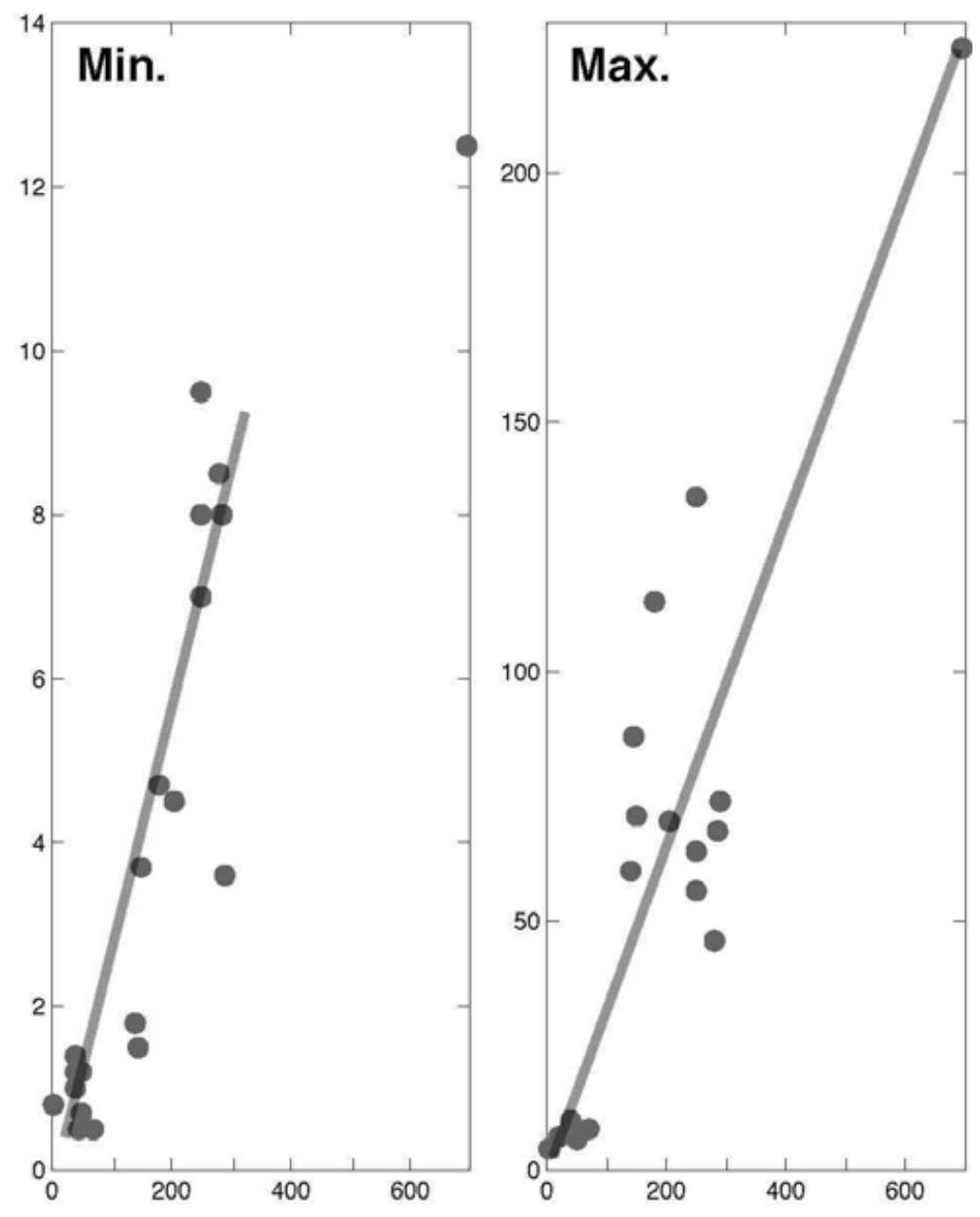

Distance to detachment (m) 
Fig. 9
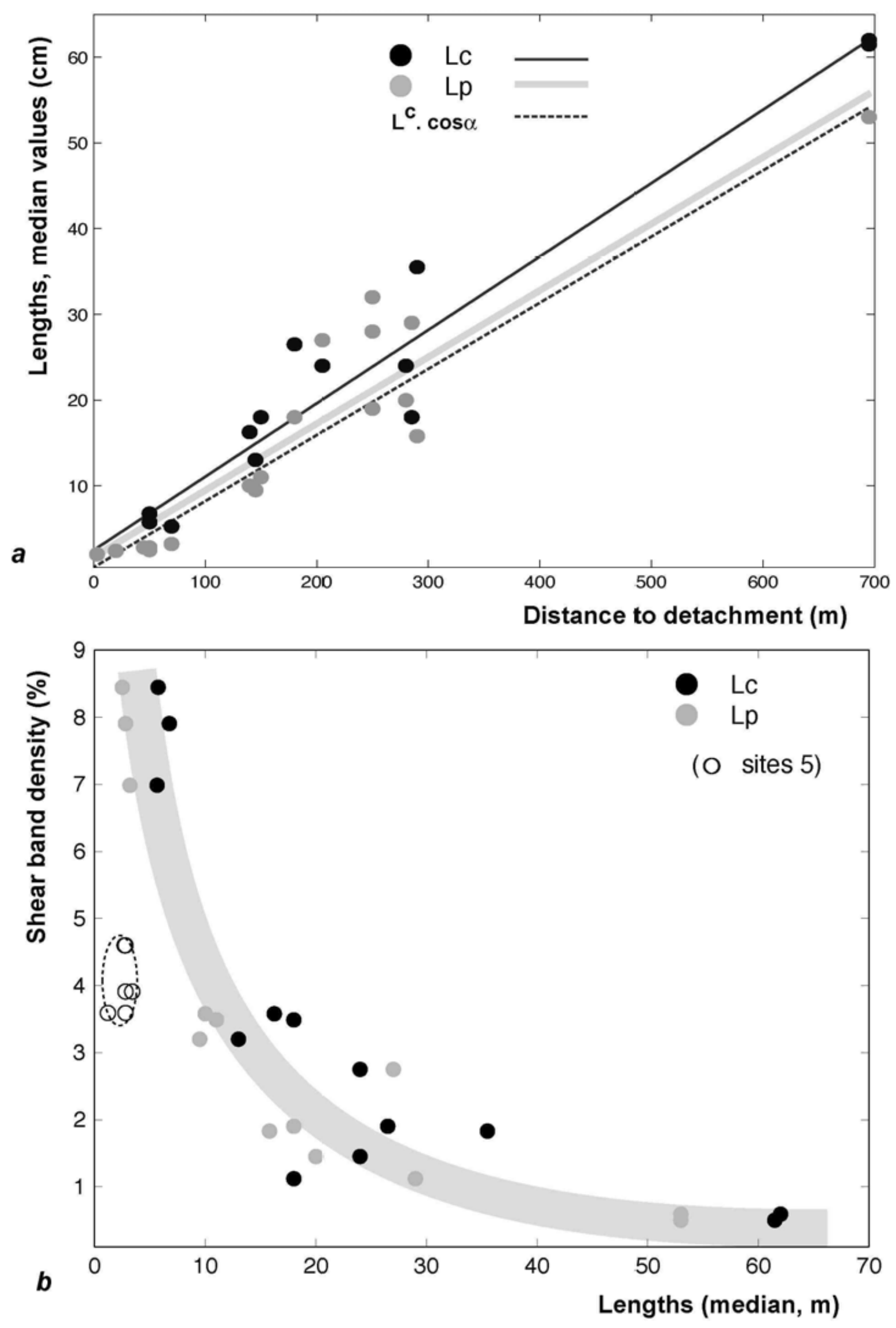
a

Fig. 10

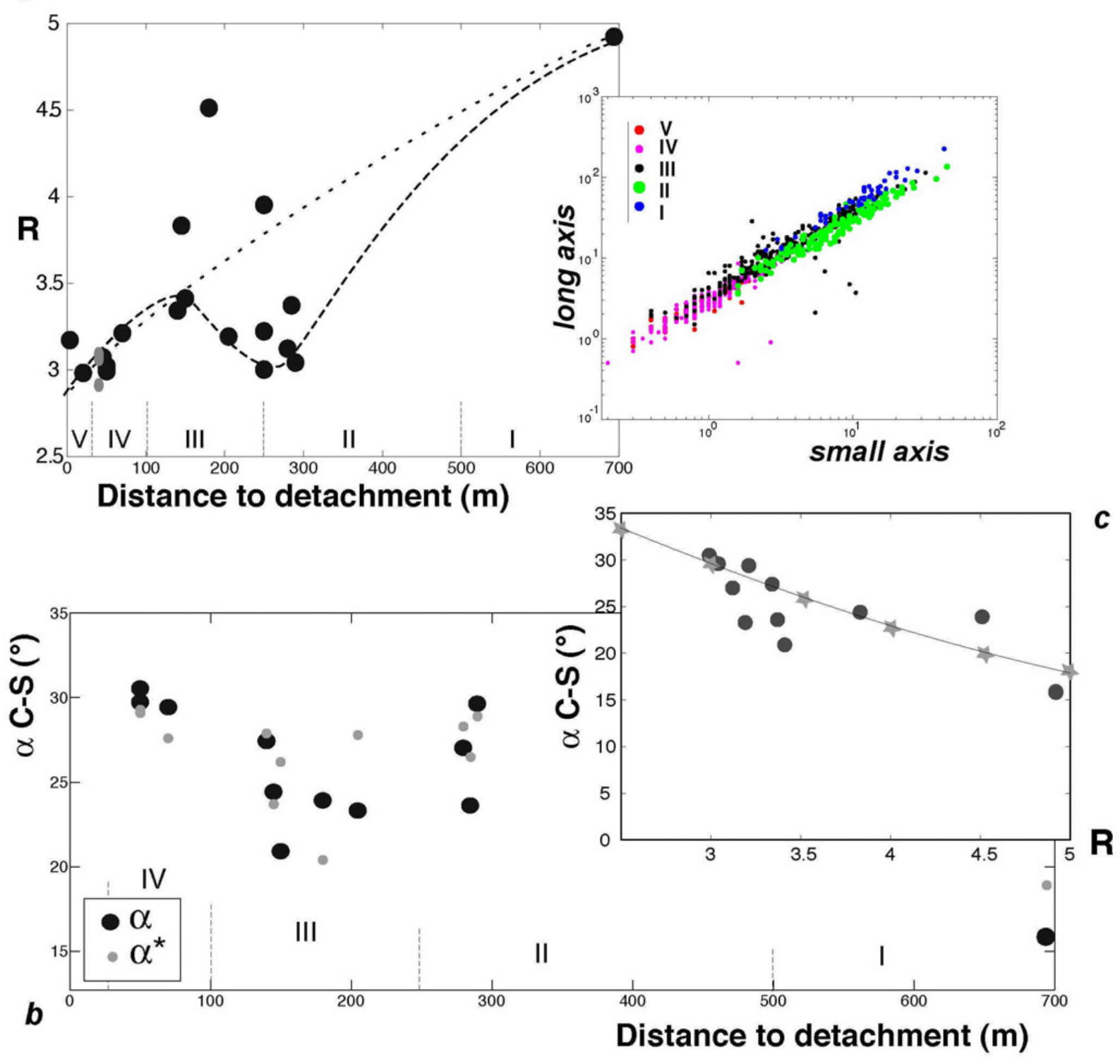


Fig. 11

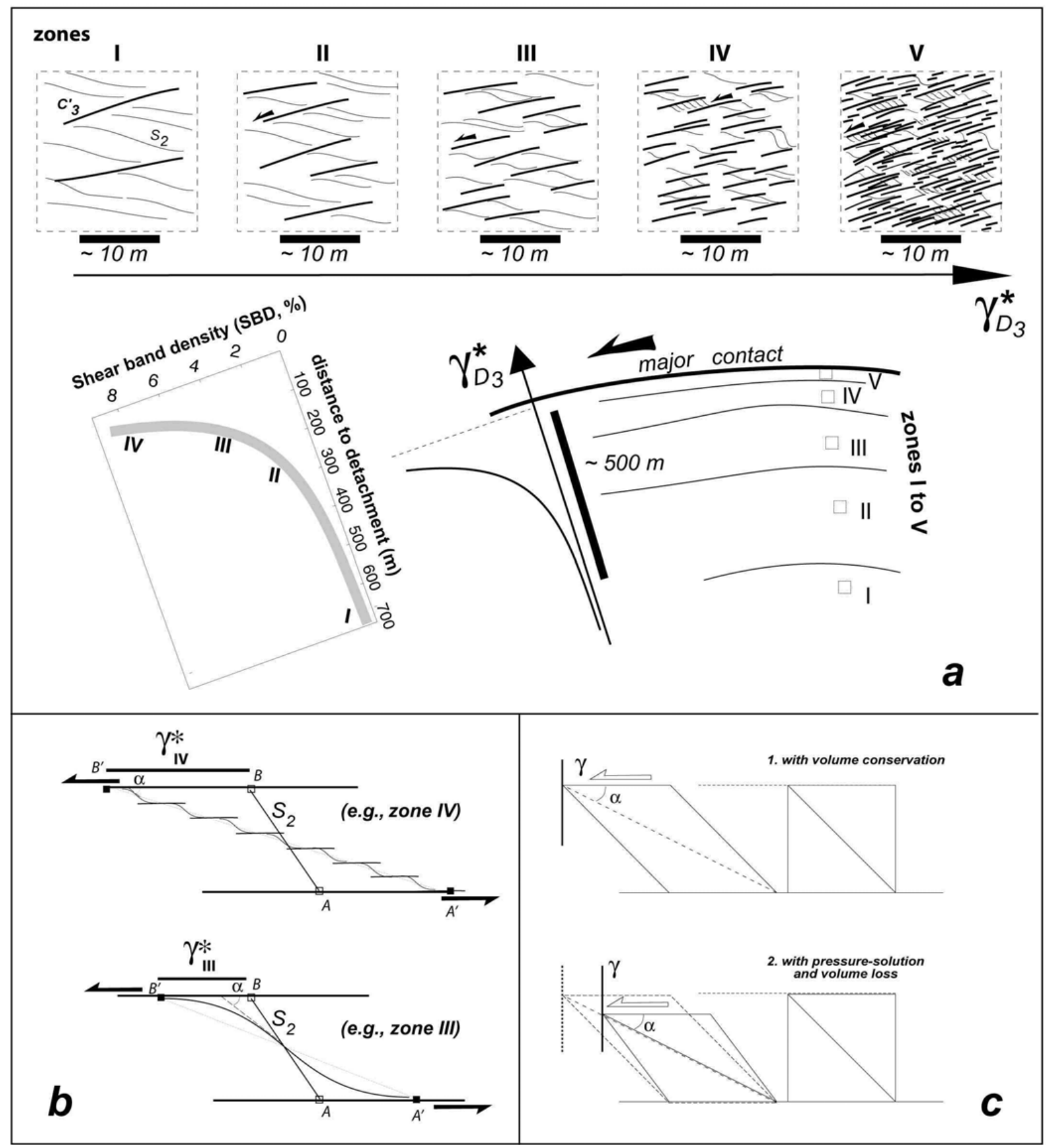


Fig. 12

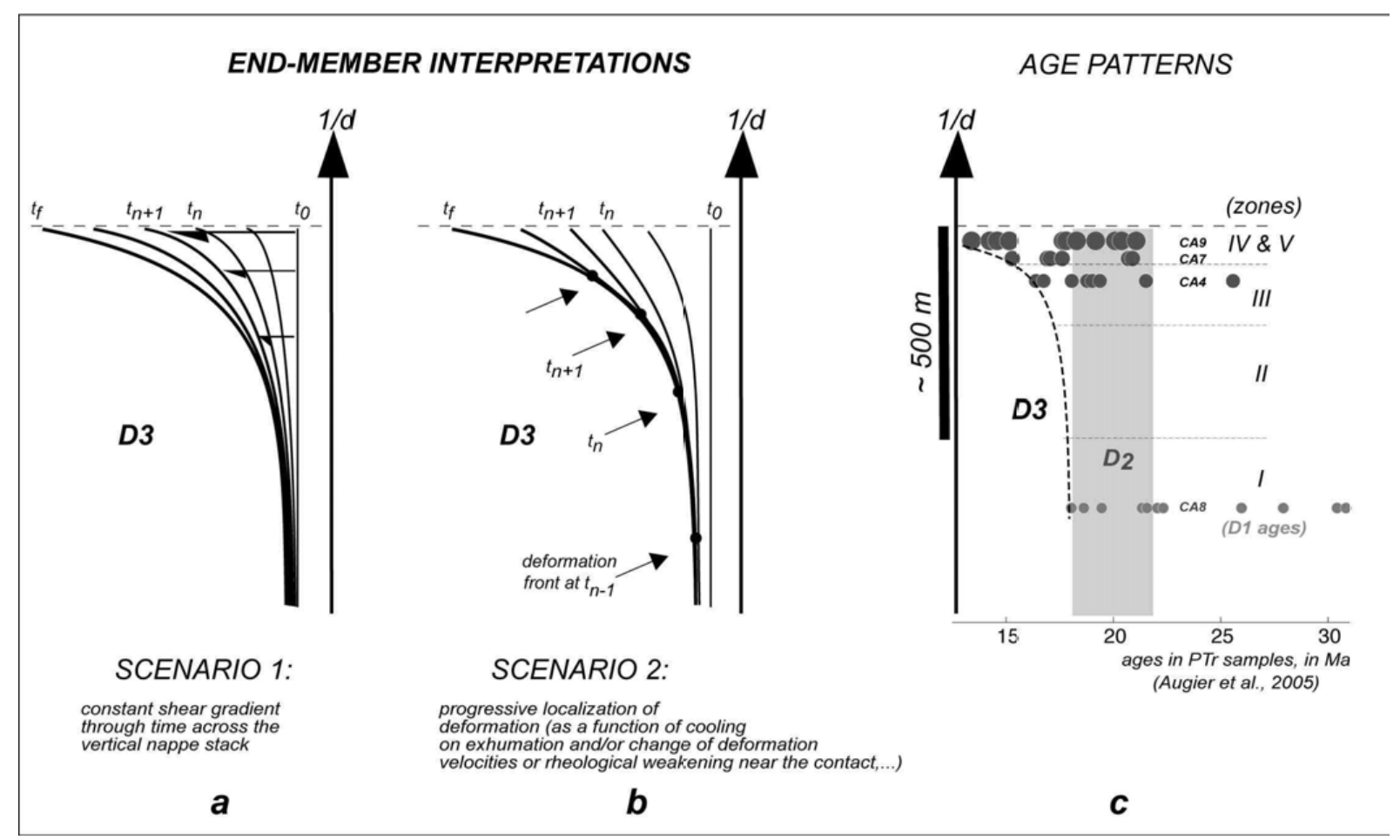




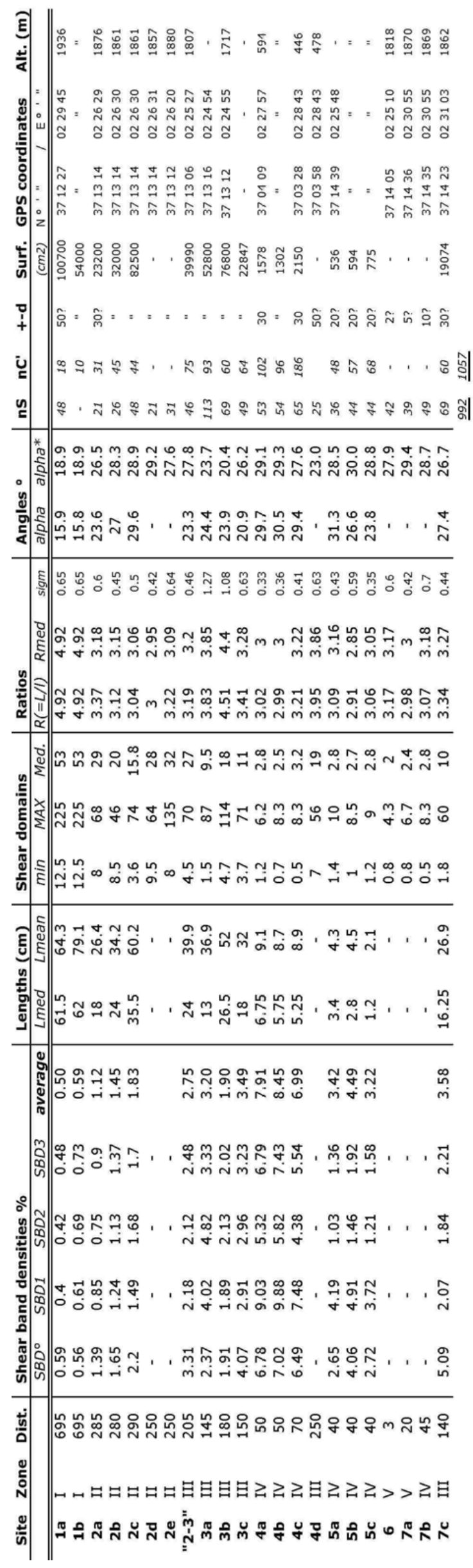


